This item was submitted to Loughborough's Research Repository by the author.

Items in Figshare are protected by copyright, with all rights reserved, unless otherwise indicated.

\title{
Complaint management expectations: an online laddering analysis of small
} versus large firms

\section{PLEASE CITE THE PUBLISHED VERSION}

http://dx.doi.org/10.1016/j.indmarman.2009.05.008

\section{PUBLISHER}

(C) Elsevier Inc.

VERSION

AM (Accepted Manuscript)

\section{LICENCE}

CC BY-NC-ND 4.0

\section{REPOSITORY RECORD}

Henneberg, Stephan C., Thorsten Gruber, Alexander E. Reppel, Bahar Ashnai, and Peter Naude. 2019. "Complaint Management Expectations: An Online Laddering Analysis of Small Versus Large Firms". figshare. https://hdl.handle.net/2134/11929. 
This item was submitted to Loughborough's Institutional Repository (https://dspace.lboro.ac.uk/) by the author and is made available under the following Creative Commons Licence conditions.

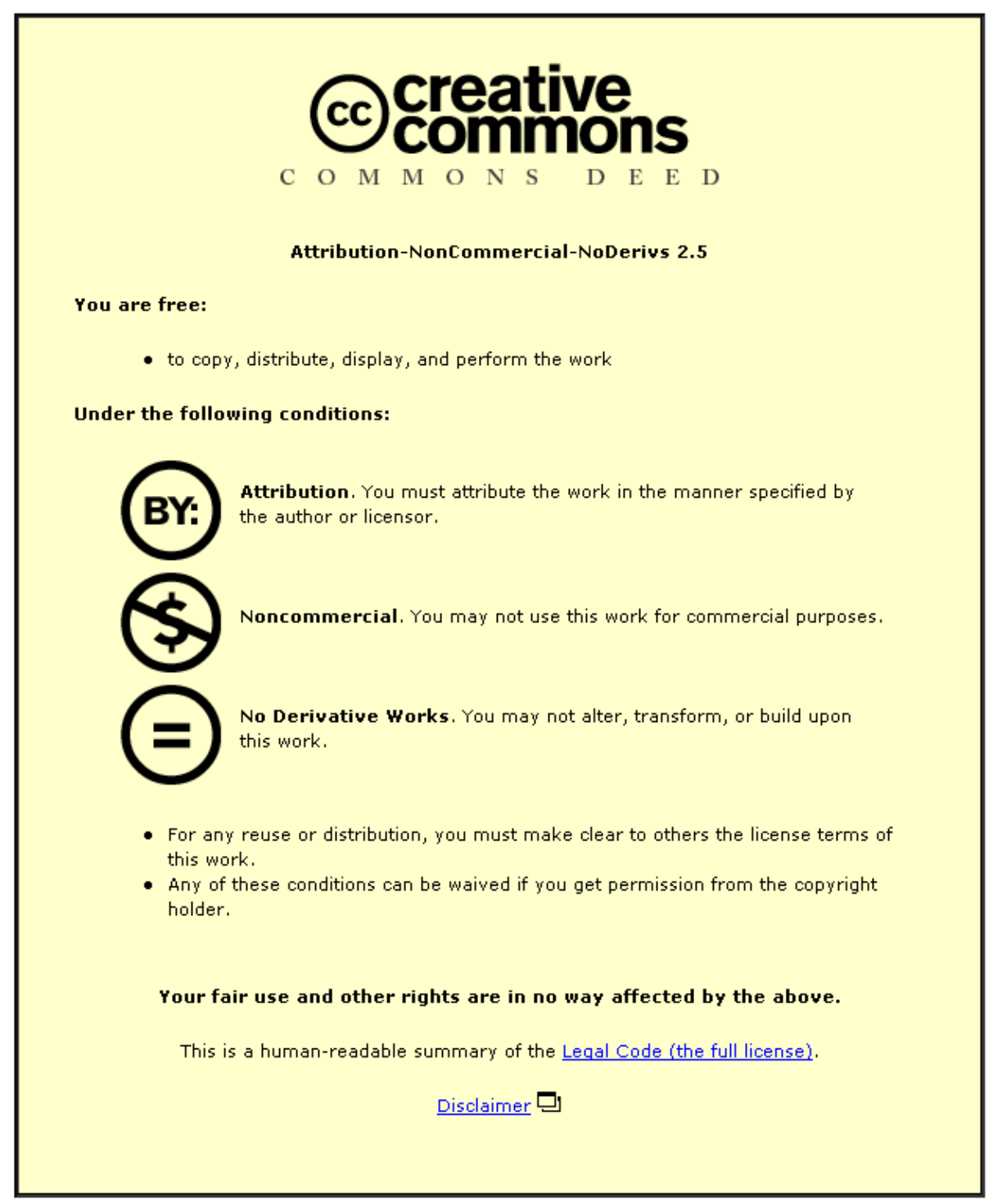

For the full text of this licence, please go to: http://creativecommons.org/licenses/by-nc-nd/2.5/ 


\title{
Complaint Management Expectations: An Online Laddering Analysis of Small versus Large Firms
}

\author{
Stephan C. Henneberg * \\ Thorsten Gruber * \\ Alexander Reppel ${ }^{\text {\$ }}$ \\ Bahar Ashnai * \\ Peter Naudé * \\ * manchester IMP Research Group \\ Manchester Business School \\ The University of Manchester \\ ${ }^{\$}$ School of Management \\ Royal Holloway \\ University of London
}

Submitted for Review

\section{Industrial Marketing Management}

IMP 2008 Conference Special Issue

Original Submission November 2008

Revised Submission March 2009

Second Revised Submission May 2009

Corresponding author: Stephan C. Henneberg, Manchester Business School, The

University of Manchester, Booth Street West, Manchester M15 6PB, UK, Tel.: +44-

(0)161-306 3463, Email: Stephan.Henneberg@ mbs.ac.uk 


\section{Author Biographies}

Stephan C. Henneberg is a Senior Lecturer/Associate Professor in Marketing at Manchester Business School, University of Manchester, UK. He obtained his Ph.D. in Marketing from the University of Cambridge, Judge Business School. His current research interests are in the areas of strategic marketing, relational marketing, consumer behaviour, strategic competences, and social and political marketing.

Address: Manchester Business School, The University of Manchester,Booth Street West, ManchesterM15 6PB, UK; Email: Stephan.Henneberg@mbs.ac.uk

Thorsten Gruber is a Lecturer/Assistant Professor in Marketing at Manchester Business School, University of Manchester. He received his Ph.D. and MBA from the University of Birmingham. His research interests include consumer complaining behaviour, services marketing and the development of qualitative online research methods.

Address: Manchester Business School, The University of Manchester,Booth Street West, ManchesterM15 6PB, UK; Email: Thorsten.Gruber@mbs.ac.uk

Alexander Reppel is a Lecturer/Assistant Professor in Marketing at the School of Management, Royal Holloway, University of London. His research interests include relationship marketing, consumer behaviour, new product-development, online research methods, and consumer data management practices.

Address: Royal Holloway, University of London, Egham, Surrey, TW20 OEX, UK, Email: Alexander.Reppel@rhul.ac.uk 
Bahar Ashnai is a Research Assistant and PhD student at Manchester Business School, University of Manchester. Her research interests are industrial marketing, business relationships, and quantitative methods in marketing. Address: Manchester Business School, The University of Manchester,Booth Street West, Manchester M15 6PB, UK; Email: Bahar.Ashnai@mbs.ac.uk

Peter Naudé is Professor of Marketing at Manchester Business School, University of Manchester, UK. He gained his Ph.D. in Marketing from the University of Manchester. His research interests are in quantitative modelling and B2B Marketing. Address: Manchester Business School, The University of Manchester,Booth Street West, ManchesterM15 6PB, UK; Email: Peter.Naude@mbs.ac.uk 


\title{
Complaint Management Expectations: An Online Laddering Analysis of Small versus Large Firms
}

\begin{abstract}
This study explores complaint management expectations in business relationships, with particular emphasis on the qualities and behaviours that affect buying companies as part of the complaint handling encounter with a supplier, specifically the business logic or motivation which drives their expectations. An exploratory empirical study uses a hard laddering approach which also allows us to compare the expectations of large and small companies to understand size-effects. The research indicates that complaining companies perceive disruptions of their supplier relationships in the context of the business network within which they are embedded, especially vis-à-vis the benefits associated with longterm supplier ties, but also in the context of the effects on down-stream customers. However, these network concerns are more pronounced for large companies. Issues of effective complaint management in business-to-business settings therefore need to be addressed not just as isolated managerial activities with limited benefits for the parties involved, but should be seen as being part of a wider activity set of strategic networking activities with an impact on whole business systems. This article provides a methodological contribution based on testing online hard laddering in business marketing. Furthermore, the findings enrich the existing limited stock of knowledge on the context of complaint management in business relationships and networks.
\end{abstract}

\section{Keywords}

Complaint Management, Business-to-Business, Supplier Relationships, Laddering, Means-End Approach 


\section{Complaint Management Expectations: An Online Laddering Analysis of Small versus Large Firms}

\section{Business Relationships, Interactions, and Complaints in Small and Large \\ Companies}

Understanding business relationships between companies is an important aspect of contemporary marketing theory and practice (Anderson, Håkansson, \& Johanson, 1994; Parolini, 1999). Collaboration and cooperation with customers, suppliers, and other organizations within business networks often characterize business marketing activities (Achrol \& Kotler, 1999). Such exchange structures result in long-term business relationships, the basis for which are a certain degree of trust, commitment, interdependence, as well as mutual relationship-specific investments and adaptations (Andersen et al., 1994; Barnes, Naudé, \& Michell, 2005; 2007; Håkansson \& Ford, 2002; Morgan \& Hunt, 1994). However, relationships are not without problems and conflicts, especially in case of power differences between the firms involved (Gaski, 1984; Hingley, 2005). Holmlund-Rytkönen and Strandvik (2005) found that most relationships are indeed characterized by some degree of stress. Imbalances with regard to the power which each partner has within a relationship (Jarratt and Morrison, 2003) are often related to such conflicts accruing (Hingley, 2005); these imbalances often manifest themselves in the relative sizes of the two companies involved, which in turn may lead to conflict (Hingley, 2005; Sanderson, 2004).

Research studies like those of the Industrial Marketing \& Purchasing Group have focused extensively on explaining business relationships, juxtaposing them with 
transactional exchanges (Håkansson, 1982; Ford et al., 2003; Ford and Håkansson, 2006). The characteristics of these relationships relate to issues such as innovation, power, risk, as well as to overall company success, and are an important competitive advantage in business markets (Deshpandé, Farley, \& Webster, 2000; Ford, 1998; Håkansson \& Ford, 2002; Ordanini, Micelli, \& Di Maria, 2004; Ulaga \& Eggert, 2006). Furthermore, much research focuses on how relationships develop and change over their life cycle, and how these relationships ultimately end (Ford, 1980; Lambe, Spekman, \& Hunt, 2000; Medlin, 2004; Schurr, Hedaa \& Gersbro, 2008; Sutton-Brady, 2008). While many aspects of the relationships between companies within business networks are well understood, the particular interaction patterns between companies, which result in business relationships, are insufficiently conceptualized (Möller \& Halinen, 1999; Uzzi, 1997; Holmlund, 2004; Ford \& Håkansson, 2006). This finding is especially true for aspects of conflict and stress, resulting in complaint behaviour and complaint management which represent interactions that are assumed to impact on the performance of the underlying relationship (Duarte \& Davies, 2003; Vaaland \& Håkanssen, 2003; Blois, 2008). Such stresses, and hence complaints, are of course to be expected in the episodic interactions between companies in any network. Indeed, it can be argued that "The absence of conflicts or difficulties in a relationship is not necessarily a good sign" (Ford et al., 2001: 44). As argued by Ford et al., (2003) confrontation and coercion are two of the action which underpin the networking activities of companies, and hence the resolution of problems or complaints forms an integral part of managerial activity within a networked environment. As such, our study's focus on complaint situations specifically addresses the aspect of 
‘elements and processes of interactions’ as one of Håkansson’s (1982) characteristics of a business relationship.

Even in close and well-performing buyer-supplier relationships, things occasionally go wrong; inter-organizational complaint resolution is therefore an important aspect of the management of ongoing business relationships (Gummesson, 2004). The managerial challenge in such cases is to understand how the firm (i.e. the supplier) ought to behave to remedy a situation in which a complainant (i.e. an organizational buyer) voices dissatisfaction with the interaction. Thus, identifying the complaint management attributes which are desired by the complaining party, becomes pivotal. Providing a timely and appropriate solution to a problem causing a complaint needs to be based on understanding the underlying motives and benefits as to why this complaint situation and specific resolution characteristics are of value to the suppliers (the complainant), and how these complaint resolution attributes thereby contribute to the continuation of the business relationship (Hansen, Swan, \& Powers, 1996b; Homburg \& Fürst, 2005). Previous studies have not addressed these issues, and we thus add to the existing literature by providing a foundation for business complaint management (by analysing the customer expectations regarding optimal complaint resolution), as well as by unearthing the motivations underlying certain customer expectations in a specific interaction situation, namely a complaint (by linking complaint management attributes to higher level value considerations by customers). Understanding expectations on which interactions are based provides the foundation for a more dynamic understanding of business relationships (Schurr, 2007). 
Of particular interest are differences in these customer considerations; our research specifically addresses the issues whether smaller companies have different expectations compared to large companies. While research found no direct evidence supporting the idea that large and small companies might address complaint resolution in different ways due to relationship imbalance (Jarrat and Morisson, 2003), it can be assumed that relational factors (such as power differences between supplier and buyer) affect the resolution management in these circumstances (Ringberg, Odekerken-Schröder \& Christensen, 2007; Blois, 2008). Furthermore, a link with power differences within business relationships could be constructed as large buyers are (or are perceived to be) in a generally more powerful position vis-à-vis their suppliers (Hingley, 2005), and therefore it can be assumed that smaller customer companies are more accommodating and interested in a continuation of important supplier relationships than larger companies (Gaski, 1984; Vaaland \& Håkansson, 2003). This is in line with what Clark (2000) has called the available "zones of manoeuvre" (299), i.e. the fact that the interaction characteristics (such as size and perceived power) impact on the expectations and activities of companies (Sanderson, 2004).

This paper addresses the managerial issue of understanding the context of the expectations of small versus large companies regarding complaint management. We use a semi-standardised qualitative laddering technique in an exploratory way which helps understand how buying companies of differing sizes operating within close business relationships expect their complaints to be handled. Additionally, the identified complaint management attributes are put into the context of desired higher-level company values, 
using a means-end approach. We therefore link complaint management attributes to more general company level motives.

The study proceeds as follows: our starting point is represented by an overview of the literature on business-to-business complaints, leading to an outline of the research methodology based on means-end theory. In a next step, we describe our data analysis method and the findings. Theoretical as well as managerial implications conclude the study.

\section{Business Complaint Behaviour and Management}

The management of complaints is a well-researched area of business-to-consumer marketing (e.g. Johnston \& Mehra, 2002; Tax, Brown, \& Chandrashekaran, 1998;

Tronvoll, 2007). However, similar literature in business marketing is scarce. This neglect is surprising, since the business-to-business literature consistently stresses the importance of effective relationship management (Håkansson \& Ford, 2002; Low \& Koon, 1997; Ojasalo, 2004). Existing research mainly compares the way in which organizations handle complaints or the effect these activities have on buyer satisfaction (Durvasula, Lysonski, \& Mehta, 2000) (see appendix A1 for an overview table of existing research). Homburg and Fürst (2005, p. 108) posit that "after a complaint, loyalty depends essentially on complaint satisfaction and not as much on satisfaction that has cumulated over time".

A seminal starting point for research in this area is Trawick and Swan's (1981) proposed model of satisfaction within industrial complaining behaviour which identifies processes and attitudinal variables. A number of further studies (e.g. Dart \& Freeman, 
1994; Hansen, 1997; Hansen et al. 1996b; Hansen, Powers, \& Swan, 1997a; Hansen, Swan, \& Powers, 1997b; Hansen, Swan, \& Powers, 1996a; Williams \& Rao, 1980) provide additional contextual clarifications of this model. For example, clear differences exist between business buyers and final consumers: those exhibiting passive complaint behaviour, i.e. whose intentions to complain were below average on all factors, represent the biggest cluster with forty-two per cent of the business sample, as opposed to only fourteen per cent of end consumers (Dart \& Freeman, 1994; Singh, 1990). Perrien, Paradis, and Banting's (1995) research specifically emphasizes the important roles of front line people: Analyzing the dissolution process of business relationships, their study shows that account managers attribute more than ninety per cent of disengagement decisions to the behaviour of their own (selling) organization, with the main responsibility resting on unsatisfactory internal management and complaint procedures.

While some understanding of complaint behaviour in business-to-business settings exists, studies investigating specifically the selling company's complaint management are rare. Often, these studies stipulate the provision of a timely solution to the problem causing the complaint without unearthing further interaction mechanisms and motives as to why (and in what kind of context) this is important. However, in a comparative setting, Homburg and Fürst (2005) analyze business-to-business as well as business-to-consumer complaint management. They find that a mechanistic approach based on establishing guidelines, and an organic approach based on creating a favourable internal environment, both significantly influence satisfaction levels of the complaining customer. However, the mechanistic approach shows a stronger overall impact, which is 
more pronounced in business-to-consumer compared to business-to-business settings, and with service firms compared to manufacturing firms.

We conclude that the existing knowledge about the motivations for and expressions of business complaint behaviour, and the knowledge of the expectations regarding complaint management and desired resolution attributes by business customers is rather limited. Therefore, managerial suggestions for an optimal complaint management process as part of business relationship interactions are rare. Most studies merely infer managerial implications from investigating complaint behaviour but do not provide a context as to why certain complaint resolution attributes provide value to the buyer. Beyond some initial insights into business complaint management (such as Hansen et al.'s (1996a) statement about the importance of buyer involvement in resolving complaints successfully), no comprehensive and rigorous understanding of the contextual drivers of effective complaint management expectations exists. For such a conceptualization, the link between expected complaint resolution attributes and buyer's value perceptions as part of means-end considerations needs to be explored. Thus, the buying company's context for certain complaint management expectations represents the focus of this study.

\section{Research Methodology and Design}

Our exploratory study aims at analyzing different levels of customer expectations in close business relationships regarding important aspects of complaint resolution attributes, based on a comparison of small and large companies. In-depth interviews are a possible way to gauge perceptions, attitudes, and expectations. However, this approach 
does not allow for a systematic comparative analysis, for example regarding the respective strength of the construct relationships (DeRuyter \& School, 1998; Johnston, Leach, \& Liu, 1999). We therefore use a laddering technique for operationalization and analysis purposes, in line with research done on similar topics in the business-toconsumer area (Gruber, Szmigin, \& Voss, 2006),

\subsection{Laddering Approach and Means-End Theory}

Laddering techniques and their foundation in means-end theory have not been used widely in business-to-business research. That this technique has hitherto been neglected is somewhat surprising as consumer research uses laddering widely, predominately for brand or product positioning issues (Gutman, 1982; Olson \& Reynolds, 1983), and recently research areas such as sales management (Deeter-Schmelz, Kennedy, \& Goebel, 2002, 2008), services marketing (Gruber et al., 2006; Voss, Gruber, \& Szmigin, 2007), and new product development (Reppel, Szmigin, \& Gruber, 2006), also apply laddering. A reason for this neglect in business research may relate to the fact that analyzing means-end ladders needs to be based on a relatively homogeneous set of respondents (Grunert \& Grunert, 1995), and thus the comparability of the participating companies needs to be controlled carefully.

However, some isolated laddering studies exist in business research, for example, the investigation into loyalty drivers of business customers by Ringberg and Gupta (2003). Jarratt (1998) uses unstructured laddering interviews for a study investigating the nature of regional business alliances. Means-end theory is also used with a small sample 
of ten respondents to explore supply chain partners' value matches and mismatches (Davis-Sramek, Fugate, \& Omar, 2007).

We use in this study an online laddering approach in the context of business-tobusiness complaint management. Laddering techniques reveal the relationships which exist between the attributes of products, services or individuals (i.e. means), the consequences these attributes represent for the respondent (e.g. a customer), and the values or beliefs which are strengthened or satisfied by the consequences (i.e. ends) (Reynolds \& Gutman, 1988):

- Attributes are the tangible and intangible characteristics of an offering (in the present study these are the characteristics of complaint resolution management).

- Consequences are the reasons why certain attributes are important to the customer. They are, according to Gutman (1982), the psychological, physiological, or process results that customers think they can achieve by using the product or service (in this study, by achieving a certain complaint resolution result).

- Values are the customers' universal life and company goals. They represent the most personal and general consequences individuals or organizations are striving for (Rokeach, 1973).

A holistic context is provided by understanding consequences and values, therefore allowing for an understanding of the motivation as to why buying companies have expectations in terms of complaint management attributes and resolution characteristics. Consequences (a midlevel of abstraction) are more relevant to the goals of a consumer, manager, or organization, than attributes (low level of abstraction); values (high level of 
abstraction) are in turn more relevant to the overall goals than consequences (Olson \& Reynolds, 1983). A progression towards increasingly higher levels of abstraction and desired ends is analysed, reflecting progress from the offering to aspects of customers' and buying companies' self concepts, goals, and basic motivations (Gutman, 1997).

Laddering usually involves semi-standardized personal in-depth interviews, with the interviewer probing to reveal attribute-consequence-value chains (i.e. ladders). The interviewer repeatedly questions why an attribute, a consequence, or a value is important to the respondent, with the answer acting as the starting point for further questioning. This is continued until saturation is reached. A graphical representation of a set of meansend chains known as a Hierarchical Value Map (HVM) summarizes the cognitive concepts gleaned during the laddering interview and analysis (Gengler, Klenosky, \& Mulvey, 1995).

Our study uses a so-called hard laddering approach, implemented via an online questionnaire. This approach distinguishes itself from soft laddering which utilizes indepth interviews where respondents are minimally restricted (Botschen \& Thelen, 1998). In both cases, researchers analyse the meaning of the answers and develop a means-end model (Grunert, Beckmann, \& Sørensen, 2001). While the majority of published meansend studies (specifically in business-to-consumer research) use soft laddering interviews; only a few use questionnaires to collect hard laddering data (Walker \& Olson, 1991). Botschen and Hemetsberger (1998) advocate hard laddering due to the fact that it reduces interviewer bias and minimizes social pressure on the respondents, especially regarding when they want to end the laddering process. Other positive characteristics of hard laddering are its cost- and time-efficient data collection, and its quicker data analysis 
compared to soft laddering. Further, Herrmann, Huber and Gustaffson (1997) found in their study on the automotive industry that both soft and hard laddering techniques provide very similar results. Several researchers (e.g. Botschen \& Hemetsberger, 1998; Botschen \& Thelen, 1998; Goldenberg et al., 2000) employ paper-and pencil versions successfully in their studies. Our study uses an online version of the 'hard' paper-andpencil design instead of conducting personal interviews. We developed (based on existing studies such as Botschen \& Hemetsberger, 1998; Pieters, Botschen, \& Thelen, 1998) and extensively pre-tested a detailed laddering explanation for our study with a sub-set of the managers of the later study.

\subsection{Study Design}

For our main study, we specifically selected smaller buying companies (below 500 employees; sample average of 120) and larger ones (500 or more employees; sample average of 2400) to understand if the characteristics of the complaining company have any effect on their expectations regarding complaint management attributes, consequences, and values and to gauge the possible impact of issues of relative power in the close business relationship (Ford et al., 2003). Companies in both size clusters were randomly selected from a commercial list of the UK manufacturing industry and managers with responsibility for supplier relationship management were phoned between September and October 2007 to solicit their participation in this study.

Respondents include purchasing managers, organizational buyers, and supply controllers. We controlled for whether the managers were influential in the purchasing and complaint decisions as well as the expertise these managers had in managing supplier 
relationships (e.g. by only using knowledgeable purchasing managers with at least 5 year's experience in their function). This is important as organizational buying decisions are usually done by a buying centre (Johnston and Lewin, 1996); however, complaint activities can be activated by individual actors. If a manager agreed to participate in the study, an email with a link to the pre-tested online-questionnaire was sent. In the questionnaire we asked the respondents to consider particularly close business relationships with suppliers in which they had also experienced problems, and then to think about how the respondents and their company would have liked this complaint to have been addressed. In particular, respondents were asked about how suppliers ought to handle their complaints and what kind of qualities or complaint management characteristics they expected. We thus use the normative concept of desired expectation levels in our study to gauge the respondents' opinions (Parasuraman, Zeithaml, \& Berry, 1988; Boulding, Kalra, Staelin \& Zeithaml, 1993). Desired expectation levels go beyond what typical characteristics of good complaint management are, or what the quality of the best provider of complaint management currently is (Cadotte, Woodruff \& Jenkins, 1987; Liljander and Strandvik, 1993; Ngobo, 1997). Using particular and close business relationships in one industry ensures homogeneity of the case analyses, which is in line with basic assumptions of means-end theory (Grunert \& Grunert, 1995; Reynolds \& Gutman, 1988).

The online approach to data collection as part of hard laddering was pretested and showed several benefits: data does not have to be recorded and transcribed as the collected data is already in electronic form. Furthermore, the whole process is perceived to be more convenient for the respondents as they can fill in the laddering questionnaire 
at their own convenience (Wood, Griffiths, \& Eatough, 2004). We also pre-tested an approach based on the laddering questionnaire attached to an email. However, this method was not used in the main study as several disadvantages became apparent: firstly, potential respondents decided not to download the attached questionnaire fearing computer viruses. Secondly, some respondents did not possess the necessary programs to open the document. Finally, respondents had to return the filled-in document, which they considered too demanding or time consuming (Gunter et al., 2002). Consequently, the final study used a website instead which hosted the questionnaire; the email we sent consisted of an outline of the research project and the link to this website.

In the online questionnaire, respondents were asked first to write down the three most important attributes or characteristics of a supplier's complaint management. They were urged to be as specific as possible. For this purpose, respondents were presented with three free text boxes to type in their chosen attributes. These were then are referred to in the subsequent laddering questions. On the next screen page, respondents used a large open text box to answer why the first attribute they had just identified was important to them. For this purpose they were, for example, asked "You have stated that one of the most important attributes or characteristic of a supplier in cases of complaints should be 'Take Responsibility'. Could you please explain to us what you mean by this and why exactly this attribute is important to you?" In a second prompted text box, respondents subsequently specified why what they indicated in the first box was important to them. If requested by the respondents, a third (and additional boxes) continued in the same way. After having completed the laddering process for the first attribute, respondents were then prompted to fill in text boxes for the second and third 
most important supplier attributes as well. The following figure illustrates the laddering process:

Insert Figure 1 about here

\subsection{Data Collection and Analysis}

Reynolds, Dethloff and Westberg (2001) recommend that exploratory laddering studies should include around twenty respondents. Such a sample size can give a significant understanding of the main attributes, consequences, and values of products, services or people. We contacted 312 manufacturing companies, with 22 valid responses from large and 16 from small companies participating in the study. This response rate of 12.2 per cent is satisfactory, bearing in mind the demanding task of means-end designs (Grunert et al., 2001).

The analysis of the data using a means-end interpretation logic was done in three stages, in line with recommendations by Reynolds and Gutman (1988). Firstly, the researchers coded sequences of attributes, consequences and values (the ladder) to make comparisons across respondents. The decision-support software program LADDERMAP (Gengler \& Reynolds, 1993) helps researchers to categorize each phrase from the questionnaire as either an attribute, a consequence, or a value. The first phase involved the development of meaningful categories so that comparable phrases and data points could be grouped together. Coding is an iterative exercise of recoding data, splitting, combining categories, generating new or dropping existing categories, in line with content analysis techniques (Krippendorff, 2004; Strauss \& Corbin, 1998). The identification of categories was through phrases and key words that respondents use in 
the online laddering questionnaires, as well as from concepts from the extant literature review and from an adaptation of the Schwartz (1992) value list, which provides an overview of generally held values. Grunert, Beckmann and Sørensen (2001) point out that researchers have a lot of latitude during the coding process. They, however, do argue that the coding reliability will benefit from having parallel coders and suggest that the analyst who has conducted the laddering interview "will be the best possible coder because she or he will remember part of the context information (and also better be able to clarify matters by referring back to a tape)" (78). Furthermore, Grunert et al. (2001) suggest that a second coder who does not possess context information should carry out the same coding task in a different way. During the coding, we were sensitive to the respondents' understanding of the different constructs. This meant, for example, that we did not eliminate overlaps in the meaning of the constructs if they were clearly intended by our respondents (one example for such an overlap is Trust and Confidence). In other words, the respondents did not see a need to have mutually exclusive constructs forming their expectations (see tables A2-A4 in the appendix for verbatim examples characterizing each construct of meaning).

As context information was not available in this study due to the online nature of the data collection, two researchers with expertise in laddering analysis, but with limited knowledge of the business-to-business area, did the initial independent data interpretation. After re-conciliation of coding differences, a third researcher with experience in business-to-business research independently coded the data and compared the findings with the initial conceptualization. 
In the second stage, the number of associations between the constructs on different levels (attributes/consequences/values) was expressed by aggregating individual means-end chains across respondents, which results in an implications matrix, detailing the associations between the constructs. An implication matrix (see table 1 for an example) generally displays two different types of implications: direct implications relate to cases where one attribute/consequence directly refers to another attribute/consequence in the same ladder (i.e. without any intervening constructs). Indirect implications are two attributes/consequences in the same ladder, which are separated by at least one intervening attribute/consequence. This matrix acts as a bridge between the qualitative and quantitative elements of the laddering technique by showing the frequencies with which one code (construct) leads to another (Deeter-Schmelz et al., 2002, 2008). All identified constructs for both large and small companies can be found in the appendix (tables A2-A4).

Insert Table 1 about here

Finally, in the third stage, a Hierarchical Value Map was generated that consists of nodes representing the most important attributes/consequences/values, and of lines indicating links between concepts (Claeys, Swinnen, \& van den Abeele, 1995). Such a HVM normally consists of three different levels relating to the three concepts of meaning: attributes, consequences, and values. Frequently, the lower section of the map is crowded and cluttered due to the normally large number of attributes obtained during laddering 
(Gengler et al., 1995). Therefore, avoiding several crossing lines (i.e. overlapping ladders) is important in enabling easier interpretability of the HVM.

In the analysis, associations between constructs are cut-off at level 2, meaning that linkages have to be mentioned by at least two respondents to be represented in the HVM. Higher cut-off points increase the interpretability of the map but result in information loss. The cut-off level of two is chosen as the resulting map keeps the balance between data reduction and retention (Gengler et al., 1995), and between detail and interpretability (Christensen \& Olson, 2002).

\section{Results and Discussion}

\subsection{Complaint Management Expectations of Large Companies}

Twenty-two questionnaires were returned by large manufacturing industry companies. Thirty-one concepts of meaning which remained above the cut-off level of two are represented in the HVM (see Figure 2). The lowest level of abstraction is presented by thirteen attributes which exemplify the complaint resolution management expectations. Within the identified ladders, fourteen constructs represent consequences of such resolution activities, while four constructs can be interpreted as being on the highest level of abstraction, i.e. values.

Insert Figure 2 about here

For large companies, Take Quick Action ${ }^{1}$ is the most important of the expected attributes and behaviours of complaint resolution management. However, as it was only mentioned nine times (i.e. only by slightly more than one third of the responding large

\footnotetext{
${ }^{1}$ Construct names are capitalized in the text to aid better readability.
} 
companies), it does not dominate the attribute list, compared to Understanding Problem or Openness (both mentioned five times). However, several other 'soft' attributes, i.e. those which are not directly problem-related such as Active Listening and Honesty are not perceived to be pivotal, contradicting findings that attributed relational importance to issues of conflict communication (Vaaland, 2006). These soft attributes represent more general attributes, which are linked to the relationship atmosphere in which long-term business interactions take place (McNally \&Griffin, 2007); however, larger companies are predominantly focusing on the specific attributes related to complaint resolution activities. Therefore, issues around the construct of Trust did not even make the cut-off level for the HVM analysis, contrasting with the important role trust plays in the literature on business relationships in general (Andersen \& Kumar, 2006; Huemer, 2004; Morgan \& Hunt, 1994; Mouzas, Henneberg, \& Naudé, 2007; Svensson, 2004; Young, 2006). The next step on the ladder of the HVM for large companies represents consequences, i.e. the immediate reasons why certain complaint resolution attributes are important. Four consequences dominate: Financial Benefits, Prevention of Future Problems, Solution, and Effective Resolution Handling (mentioned by eleven, twelve, twelve, and eleven respondents respectively). While one of these consequences is focused on the complaint management process (i.e. Effective Resolution Handling), the other three are outcome-related, with Prevention of Future Problems linking the complaint incident to the improvement of future interactions between the key suppliers and the customer company. Compared to other studies on complaint resolution management, it is surprising that the construct Solution does not exhibit a more dominant position in the HVM for large companies (Henneberg et al., 2008; Trawick \& Swan, 1981). While the 
strongest path links the attribute of Take Quick Action to Solution, its impact on values is clearly mediated via other consequences, e.g. via Save Time, and Financial Benefits.

With regard to the value level of the means-end ladder, four different constructs as the highest desired results are identified. These can be understood as the overarching ends as to why complaint resolution management in close business relationships is of importance to manufacturing companies. In line with results from other comparable laddering studies, only a relatively small number of constructs are at this highest level of abstraction (Botschen \& Hemetsberger, 1998). Maintain Supplier Relationships is dominant in the perceptions of companies, with half of them mentioning this as an end. The concern for the continuity of the relationship which was already visible via the importance of the consequence of Prevention of Future Problems reveals the inherent interdependence that is evident in close relationships with key suppliers, even in asymmetric relationships. Complaint situations need to be resolved not just to remedy a specific problem but to ensure the continued availability of crucial resource interactions via the supply network as part of the relationship brokerage activities of business exchanges (Harland \& Knight, 2001).

However, this concern with maintaining supplier relationships is not equally mirrored to the same extent by a concern for down-stream exchanges as part of valuecreating systems (Parolini, 1999): Maintain Customer Relationship was only mentioned by three respondents. The impact of relationship issues with a company's suppliers on their customers (Network Effect), indicating that the interdependencies of a demand chain (Jüttner, Christopher, \& Baker, 2007) are also important but not top-of-mind for larger manufacturing companies (mentioned by four respondents). This is exemplified by 
the value of Reputation Benefits. Companies relate critical incidences in a business relationship and how they are dealt with to the possible effects on their own reputation. This can be directly linked to the attribute of Take Quick Actions, i.e. the supplying company needs to react to a complaint quickly, implying that the customer company (the complainant) needs to enable this by active and constructive complaint behaviour. This backs Hicks et al.'s (1996) argument regarding the importance of interactions for reputational issues in business relationships. In light of this, the reticence of companies to complain (in contrast with end-consumers) reported in the literature hints at a problem for successful complaint resolution management with potential impact on the quality of crucial supplier relationships (Dart \& Freeman, 1994). Overall, larger companies seem be concerned not only with their direct relationships with suppliers, also with the systemic aspects of the necessary resource ties and pooled capabilities within business networks, in line with their focal network position due to their size/power (Andersen et al., 1994; Evans \& Berman, 2001; Stabell \& Fjeldstad, 1998).

While the laddering logic implies a hierarchical relationship between different constructs, HVMs can also be interpreted as a symmetrical interaction map in line with van Rekom and Wierenga's (2007) critique of means-end techniques. In our example, no clear centre is visible for large companies; however, the triad of Solution, Prevention of Future Problems, and Effective Resolution Handling seems to provide the linchpin linking different areas of their HVM. This illustrates that the identified expected means of complaint resolution management are important, and are mediated in a rather complex manner to achieve a small number of ends. 


\subsection{Complaint Management Expectations of Small Companies}

Using sixteen questionnaires returned by small buying companies, twenty-eight concepts of meaning above the cut-off level are represented in the HVM (see Figure 3). Ten attributes present the lowest level of abstraction with regard to the complaint resolution management expectations of small companies. Within the identified ladders, fifteen constructs represent consequences, while three constructs can be interpreted as values.

Insert Figure 3 about here

In terms of the expected attributes and behaviours of complaint resolution management, Take Quick Action is the most important one (mentioned twelve times). This behaviour is expected by small buying companies as the main driver while all other attributes, although representing important expectations, have a lower impact on consequences and values (e.g. Understand Problem as the second most important attributes was mentioned only five times). Thus, companies want to see an active and action-based complaint management, not merely one based on the selling supplier understanding the issue at hand which had initiated the buying company to complain in the first place. However, several 'soft' attributes, i.e. those which are not directly problem-related can be identified as important: Active Listening, Manners, Honesty, and Motivation. While these represent more general attributes which are linked to the relationship atmosphere in which long-term business interactions take place (McNally \& Griffin, 2007), medium-sized companies are pre-dominantly focusing on the specific attributes related to complaint resolution activities. Again, the construct of Trust seems 
not to be very relevant for small companies, as it was mentioned by a minority of respondents and just reached the cut-off point for the HVM analysis. While Tyler and Stanley (2007) found that smaller companies in the financial sector generally put more emphasis on trust in business relationships, our findings cannot corroborate this for complaint expectations of small companies in the manufacturing sector.

Consequences, the next step on the ladder, represent the second level of abstraction, being the direct reasons why certain attributes are important for companies when faced with complaint resolution activities of their key suppliers. Not surprisingly, of pivotal importance for the small firms is that a Solution is reached, i.e. a resolution of the problem causing the complaint, in line with findings by other studies in this area (Trawick \& Swan, 1981). All except one respondent referred to this consequence. Solution is the direct and strong result of the attribute of Take Action, representing the dominant path linking attributes to consequences. Solution in turn results in Save Time, a benefit for the buying company. Another important consequence is represented by Financial Benefits (mentioned nine times). This construct covers aspects of counteracting possible economic problems associated with the cause of the complaint (for example, the late delivery of raw materials could cause a manufacturing production line to shut down with resulting financial losses), as well as aspects of remedial payments by the supplier. However, this consequence is again linked to the dominant construct Solution via Quality Assurance as well as Managerial Benefits. Besides these primary consequences, some process and reassurance issues also exhibit some degree of perceived importance by the buying company: Prevention of Future Problems, Effective Resolution Handling, and Take Problem Seriously. 
On the value level of the means-end ladder, three different constructs are identified as the highest desired results, providing the overarching ends as to why complaint resolution management in close business relationships is of importance to customers: Maintain Supplier Relationship, Maintain Customer Relationship, and Reputation. In line with results from other comparable laddering studies, only a relatively small number of constructs occur at this highest level of abstraction (Botschen \& Hemetsberger, 1998). Dominant in the perceptions of small companies is to Maintain Supplier Relationships as the end-construct to the dominant ladder from Take Action via Solution and Save Time. This value construct reveals the inherent interdependence that is evident in close relationships with suppliers: Complaint situations need to be resolved not just to remedy a specific problem but to ensure the continuity of crucial resource interactions via the supply network, i.e. it is part of the relationship brokerage activities of business exchanges (Harland \& Knight, 2001). Similarly to large companies, this concern with maintaining supplier relationships is not mirrored by a concern for the small company's customers.

Interpreting the HVM as a symmetrical interaction map (van Rekom \& Wierenga, 2007), Solution represent the key concept within a network of constructs. This illustrates that the identified expected means of complaint resolution management are important in manifold ways. However, the ends clearly show that small buying companies have a clear orientation towards maintaining key supplier relationships in situations when problems occur in these relationships. A primary focus on behaviours of complaint resolution management instead of relationship-enhancing signals and attitudes is clearly represented in the HVM. 


\subsection{Comparing Complaint Management Expectations of Large Versus Small}

\section{Companies}

A comparison of the different concepts of meaning related to expectations for complaint management for large and small companies in the manufacturing sector shows that large companies identify Acknowledgement of Problem (mentioned 9 times) and Openness (10) significantly more often as an important attribute than small companies (1 and 0, respectively). Similarly, Confidence (11), Effective Resolution Handling (26), Financial Benefits (26), and Prevention of Future Problems (19) feature more for large than small companies (4/8/12/9 times mentioned, respectively).

Looking at the two HVMs it becomes clear that smaller companies exhibit less complex expectations regarding complaint management than larger companies. The number of constructs involved is lower, and the HVM is dominated by one critical path. While the Solution consequence is still the central construct, it is predominantly linked to the specific complaint management attribute Take Action. Via the intermediate consequence of Save Time, it is of value because it allows for Maintaining Supplier Relationships. This can be interpreted as activating a dyadic utilitarian model of recovery expectations which is mainly aimed at quick activities to rectify problems in a close supplier relationship (Ringberg et al., 2007), in line with general expectations regarding the interplay of power and conflict in distribution channels (Vaaland and Håkansson, 2003). Nevertheless, small companies are not accommodating in their complaint management expectations as they clearly focus on quick and solution-oriented recovery activities by the supplier (Gaski, 1983). However, for large companies the HVM is much 
more complex, and several more constructs are placed in the centre without a clear critical path. Solution, Prevention of Future Problems, Financial Benefits, and Effective Solution Handling are all important consequences for these companies, linked to sellers Taking Quick Action, Openness, and Understanding the Problem. Large companies see the value of complaint management in a broader way compared to small companies; besides Maintaining Supplier Relationships they are also concerned with the impact on their own customers and the crucial relationships with them. This hints at the fact that large and powerful companies are perceived to have wider 'zones to manoeuvre' (Sanderson, 2004): larger companies perceive complaints and their handling in the context of a wider range of managerial consequences and values, and are concerned with more aspects of the complaint management process than the smaller companies. Larger companies seem to relate critical incidences which result in complaints and how they are dealt with to the possible network effects on supplier and customer relationships (and ultimately final customers), thereby applying a network utilitarian model of recovery expectations. Small companies on the other hand seem be less concerned about the systemic aspects of the necessary resource ties and pooled capabilities within business networks (e.g. Evans and Berman, 2001). These results qualify Jarratt and Morrison's (2003) finding that relationship imbalance does not significantly impact on relational practices in business relationships.

\section{Conclusion and Implications}

\subsection{Main Findings and Theoretical Implications}


The exploratory analysis and findings enrich the existing limited stock of knowledge on conflict management, and more specifically on complaint management in business relationships by developing a deeper understanding of the supplier attributes (i.e. characteristics and behaviours) that complaining customer companies desire, and specifically identify the underlying business logic (i.e. buying company's values) on which these complaint management expectations are based. However, in line with most qualitative research, the findings are specific to the situation and industry in which our study was deployed. Thus, any generalizations beyond the realm of the research design of this study remains tentative. Within these constraints, our study shows that while structurally the means-end constructs of large and small firms in our sample of the manufacturing industry are very similar, there are also considerable differences in the content of their expected complaint resolution attributes and the motives for these expectations. However, our analyses use the unit of analysis of one respondent per company. Future research needs to look at the impact of organizational interactions on complaint behaviour expectations, e.g. analogously to a buying centre a 'complaint centre' may exist.

The analysis shows that companies relate issues of complaint resolution by their key suppliers to the context of the overall business network in which they are embedded. However, this tendency is more pronounced for large in comparison to small companies. As such, the complaint management activities of supplying companies, which are often disruptive to close business relationships, provide the context of potentially impacting on other business relationships, even indirect ones involving down-stream customers. Thus, 
providing a solution to a complaint situation (i.e. exhibiting the required complaint management attributes) is not enough, based on a twofold complication.

Firstly, the analysis highlights the importance of being able to clearly and quickly analyze and address the problem causing the complaint, but also to do this in a manner that is in line with and appropriate for close business relationships. The importance of Empathy, Manners, Honesty, and Openness in the analysis shows the soft aspects of effective complaint management that arguably cannot be part of a rules-based approach (Homburg \& Fürst, 2005). Thus, a Solution is not just about remedying the situation (outcome) but includes the way in which it is done (process). This finding backs the importance of front-line managers for the complaint management process (Perrien et al., 1995).

While this result is intuitive, the second aspect provides an innovative perspective for further research: The expectations of especially large business buyers are concerned with the effect of any complaint management characteristics within a buyer-seller relationship, and especially within a network of companies, that is a value-creating system (Parolini, 1999). Complaint management attributes need to signify the essence of these business relationships, specifically the underlying motivation for continuing a collaborative business setting between two companies. Thus, the limited perspective in the extant literature on inter-firm relationships, focusing mostly on complaint attributes per se and not their motivation, needs to be re-evaluated (Davidow, 2003). Analogous to findings about different recovery expectation models operating in a business-to-consumer context (Ringberg et al., 2007), small companies seem to operate within a more limited, dyadic utilitarian set of expectations, while larger companies employ a network utilitarian 
model. Nevertheless, effective complaint management processes represent an important boundary-spanning activity as part of the inter-firm interactions in business relationships (Walter, 1999). While in itself this only represents an interaction episode (made up of individual actions), it impacts (via the expectations of the actors) on sequence and relationship aspects (Holmlund, 2004; Schurr, 2007). Further research therefore needs to link complaint management expectations and recovery activities on the one hand to relationship change on the other (Schurr et al., 2008). This necessarily needs to take into consideration complaints voiced by the selling company (Blois, 2008).

Issues of effective complaint management need to address not just isolated managerial activities with limited benefits for the parties involved, but should focus on being part of a wider activity set of strategic networking activities which potentially impact on whole business systems (Ford et al., 2003; Ritter, 1999). Furthermore, understanding key characteristics of complaining companies, such as their size, provides contingency information about differences in expectations. Complaint management effectiveness consequently relates to a wider perspective, not just the satisfaction levels of the direct complainant (Hansen et al., 1996b). Complaint management and performance thus becomes an activity with relevance to the overall business network. This result represents a key contribution of the present research which provides a wider network context for the literature on complaint management. A Solution in this context is therefore not merely a simple solution to the problem at hand (i.e. the reason for a complaint), but a solution to the ongoing question of how business relationships can be continued, enhanced, and developed within the interaction patterns of dependence and collaboration within a complex system of network relationships (Ford et al., 2003). Such 
a network perspective also includes the reverse understanding of how suppliers complain to their customers in close business relationships.

One unexpected finding from our study was the difference in approach between large and small firms. The existence of different expectation models based on relational characteristics (in our case based on the firm size of the customer company) needs to be researched in more detail, e.g. regarding different cultural models operating in different settings (Ringberg et al., 2007). A further noteworthy finding relates to the unimportance of Trust: although posited to play a key part in building close and successful business relationships (Andersen \& Kumar, 2006; Huemer, 2004; Morgan \& Hunt, 1994; Svensson, 2004; Young, 2006), it did not even make the cut-off for inclusion in our analysis. While identified as a construct of meaning in our data, Trust did not feature as an important complaint resolution attribute, for either small or large companies (in fact, small companies did not mention trust or trustworthiness at all). We can only offer some suggestions for this astonishing finding which should instigate further research. For example, it may be that relationships in the manufacturing industry are not normally related to trust. If other relational norms dominated, e.g. reliance or dependence (Heide \& John, 1988; Luo, 2002; Mouzas et al., 2007; Tellefsen \& Thomas, 2005), trust may only play a subordinate role in the expectations within this industry. Although there is no evidence that this is the case in the manufacturing industry, it has been shown to be the case in other sectors, e.g. the construction industry (Saad et al., 2002). Another possible explanation may be that the underlying characteristics which drive business relationships are different, depending on whether a critical interaction is perceived as positive or negative for the relationship. This means that business relationships are governed by two 
different sets of drivers, not by differing degrees of one overall set. Whilst positive interactions may bring business characteristics such as trust, commitment, or long-term orientation to the fore, negative interactions could manifest themselves via different constructs. Thus, complaint management resolution expectations may be directed towards such characteristics, not those usually associated with fostering business relationships.

We showed in our research that laddering studies provide a richly appropriate research design, which unlocks means-end considerations otherwise hidden from quantitative research. The quality of the results underlines the viability of a hard laddering method implemented online. In fact, the utilisation of the online approach provides evidence that complex contextual chains can be analyzed with comparable detail and quality to established hard laddering techniques implemented via a pen-and-pencil method. Further research needs to replicate these results and show the relative performance of different ways of implementing hard laddering (e.g. assisted by a graphical presentation explaining the procedure, or via a podcast), also contrasting different hard laddering techniques with soft laddering applications (Botschen \& Thelen, 1998). In this connection, Grunert, Beckmann and Sørensen (2001, p. 76) suggest that future research clarifies "under which circumstances it may be safe to perform hard laddering, and when it appears necessary to employ soft laddering". Our results show the depth of insight that can be achieved using an on-line hard laddering approach, but there is clearly room for more work in the future examining the relative benefits of different laddering approaches.

\subsection{Managerial Implications}


Our findings have some immediate managerial implications. Much of marketing has traditionally focused on understanding the attributes most salient to buyers, and assessing firms' performance on those attributes (Swan \& Combs, 1976). Our results suggest that the process of complaint management resolution needs to be optimised by not just finding the appropriate attributes, but by assessing these in a way that their impact is linked in the perception of the complaining company to the important consequences and motives. Thus, taking quick action in the case of a complaint needs to be linked with attributes which show the (large) complaining company that is not just the first step to an interaction aimed at finding a solution and addressing financial implications, but also that the complaining company is aware of the possible impact the incident underlying the complaint may have for the complainant's own customer relationships. As such, empathy with the overall situation of the complaining firm needs to be related to complaint resolution attributes, e.g. service agreements for sales personnel in dealing with complaints.

Furthermore, the research also shows that depending on the characteristics of the complaining company, different underlying consequences and values are operating with regard to influencing the complainant's expectations. Thus, complaint resolution management needs to be customised according to these characteristics. Our juxtaposition of large versus small firms in the manufacturing industry provides an initial understanding of these contextual differences for use in managerial practice. 


\section{References}

Achrol, R. S. \& Kotler, P. (1999). Marketing in the network economy. Journal of Marketing, 63 (4), 146-63.

Andersen, P. H. \& Kumar, R. (2006). Emotions, trust and relationship development in business relationships: a conceptual model for buyer-seller dyads. Industrial Marketing Management, 35 (4), 522-535.

Anderson, J. C., Håkansson, H., \& Johanson, J. (1994). Dyadic business relationships within a business network context. Journal of Marketing, 58 (4), 1-15.

Armstrong, J. S. and Overton T. S. (1977). Estimating nonresponse bias in mail surveys. Journal of Marketing Research, 14 (August), 396-402.

Barnes, B. R., Naudé, P., \& Michell, P. (2005). Exploring commitment and dependency in dyadic relationships. Journal of Business-to-Business Marketing, 12 (3), 1-26.

Barnes, B. R., Naudé, P., \& Michell, P. (2007)._Perceptual gaps and similarities in buyerseller dyadic relationships. Industrial Marketing Management, 36 ( 5), 662-675.

Blois, K. (2008). 'Exit, voice and loyalty' in buisness to business markets. The IMP Journal, 2 (1), 2-12.

Botschen, G. \& Hemetsberger, A. (1998). Diagnosing means-end structures to determine the degree of potential marketing program standardization. Journal of Business Research, 42 (2), 151-59.

Botschen, G. \& Thelen, E. M. (1998). Hard versus soft laddering: Implications for appropriate use. In I. Balderjahn, C. Mennicken, \& E. Vernette (Eds.), New developments and approaches in consumer behaviour research (pp. 321-39). Stuttgart: Schäffer-Poeschel Verlag. 
Boulding, W., Kalra, A., Staelin, R. \& Zeithaml, V. A. (1993). A dynamic process model of service quality: From expectations to behavioral intentions. Journal of Marketing Research, 30 (1), 7-27.

Cadotte, E. R., Woodruff, R. B \& Jenkins, R. L. (1987). Expectations and norms in models of consumer satisfaction. Journal of Marketing Research, 24 (3), 305-314.

Cho, Y., Im, I., Hiltz, R., \& Fjermestad, J. (2002). The effects of post-purchase evaluation factors on online vs. Offline customer complaining behavior: Implications for customer loyalty. Advances in Consumer Research, 29, 318-26.

Christensen, G. L. \& Olson, J. C. (2002). Mapping consumers' mental models with zmet. Psychology \& Marketing, 19 (6), 477-501.

Claeys C., Swinnen A., \& van den Abeele, P. (1995). Consumers' means-end chains for “think" and "feel” products. International Journal of Research in Marketing, 12: 193208.

Clark, P. (2000). Organizations in Action, Routledge, London.

Dart, J. \& Freeman, K. (1994). Dissatisfaction response styles among clients of professional accounting firms. Journal of Business Research, 29 (1), 75-81.

Davidow, M. (2003). Organizational responses to customer complaints: What works and what doesn't. Journal of Service Research, 5 (3), 225-250.

Davis-Sramek, B., Fugate, B. S., \& Omar, A. (2007). Functional/dysfunctional supply chain exchanges. International Journal of Physical Distribution \& Logistics Management, 37 (1), 43-63. 
Deeter-Schmelz, D. R., Kennedy, K. N., \& Goebel, D. J. (2002). Understanding sales manager effectiveness - linking attributes to sales force values. Industrial Marketing Management, 31 (7), 617-26.

Deeter-Schmelz, D. R., Goebel, D. J. \& Kennedy, K. N. (2008). What are the characteristics of an effective sales manager? An exploratory study comparing salesperson and sales manager perspectives. Journal of Personal Selling \& Sales Management, 28 (1), 7-20.

De Ruyter, K. \& Scholl, N. (1998). Positioning qualitative market research: Reflections from theory and practice. Qualitative Market Research, 1 (1): 7-14.

Deshpandé, R., Farley, J. U., \& Webster Jr., F. E. (2000).Triad lessons: Generalizing results on high performance firms in five business-to-business markets. International Journal of Research in Marketing, 17 (4), 353-362.

Duarte, M \& Davies, G. (2003). Testing the conflict-performance assumption in buisnessto-business relationships. Industrial Marketing Management, 32, 91-99.

Durvasula, S., Lysonski, S., \& Mehta, S. C. (2000). Business-to-business marketing service recovery and customer satisfaction issues with ocean shipping lines. European Journal of Marketing, 34 (3/4), 433-52.

Elg, U. (2008). Inter-firm market orientation and the influence of network and relational factors. Scandinavian Journal of Management, 24 (1), 55-68.

Evans, J. R. \& Berman, B. (2001). Conceptualizing and operationalizing the business-tobusiness value chain. Industrial Marketing Management, 30 (2), 135-48.

Ford, D. (1980). The development of buyer-seller relationships in industrial marketing, European Journal of Marketing, 14, 56. 339-353 
Ford, D. (1998). Two decades of interaction, relationships and networks. in Naudé, P., \& Turnbull, P. W. (Eds.), Network dynamics in international marketing, Pergamon/Elsevier Science, 1998, pp. 3-15.

Ford, D., Berthon, P., Brown, S., Gadde, L-E., Hakansson, H., Naudé, P., Ritter, T., \& Snehota, I. (2001). The Business Marketing Course: Managing in Complex Networks, Chichester, Wiley.

Ford, D., Gadde, L.-E., Håkansson, H., \& Snehota, I. (2003). Managing business relationships. Chichester: Wiley.

Ford, D. \& Håkansson, H. (2006). The idea of interaction. The IMP Journal, 1 (1): 4-27.

Gadde, L-E. (2004). Activity coordination and resource combining in distribution networks - implications for relationship involvement and the relationship atmosphere. Journal of Marketing Management, 20 (1/2), 157-84.

Gaski, J. F. (1984). The theory of power and conflict in channels of distribution. Journal of Marketing. 48, 9-29.

Gengler, C. E. \& Reynolds, T. J. (1993). Laddermap: A software tool for analyzing laddering data, version 5.4.

Gengler, C. E., Klenosky, D. B., \& Mulvey, M. S. (1995). Improving the graphic representation of means-end results. International Journal of Research in Marketing, 12), 245-56.

Goldenberg, M. A., Klenosky, D. B., O'Leary, J. T., \& Templin, T. J. (2000). A meansend investigation of ropes course experiences. Journal of Leisure Research, 32 (2), 208-224.

Groves, R. M. (1989). Survey errors and survey costs. New York: Wiley. 
Gruber, T., Szmigin, I., \& Voss, R. (2006). The desired qualities of customer contact employees in complaint handling encounters. Journal of Marketing Management, 22 (5-6), 619-42.

Grunert, K. G. \& Grunert, S. C. (1995). Measuring subjective meaning structures by the laddering method: Theoretical considerations and methodological problems. International Journal of Research in Marketing, 12 (3), 209-25.

Grunert, K. G., Beckmann, S. C., \& Sørensen, E. (2001). Means-end chains and laddering: An inventory of problems and an agenda for research. In T. J. Reynolds \& J. C. Olson (Eds.), Understanding consumer decision making - the means-end approach to marketing and advertising strategy (pp. 63-90). Mahwah, NJ: Lawrence Erlbaum Associates.

Gummesson, E. (2004). Return on relationships (ror): The value of relationship marketing and crm in business-to-business contexts. The Journal of Business \& Industrial Marketing, 19 (2), 136-48.

Gunter, B., Nicholas, D., Huntington, P. \& Williams, P. (2002) Online versus offline research: implications for evaluating digital media. Aslib Proceedings, 54 (4), 229239.

Gutman, J. (1982). A means-end chain model based on consumer categorization processes. Journal of Marketing, 46 (2), 60-72.

Gutman, J. (1997). Means-end chains as goal hierarchies. Psychology \& Marketing, 14 (6), 545-60.

Håkansson, H. (1982). International marketing and purchasing of industrial goods: An interaction approach. Chichester: Wiley. 
Håkansson, H. \& Ford, D. (2002). How should companies interact in business networks? Journal of Business Research, 55 (2), 133-39.

Hansen, S. W. (1997). Power as a predictor of industrial complaining styles in a buyer/seller relationship: The buyer's perspective. Journal of Business \& Industrial Marketing, 12 (2), 134-48.

Hansen S. W., Swan, J. E., \& Powers, T. L. (1996a). Encouraging "friendly" complaint behavior in industrial markets: Preventing a loss of customers and reputation. Industrial Marketing Management, 25 (4), 271-81.

Hansen S. W., Swan, J. E., \& Powers, T. L. (1996b). The perceived effectiveness of marketer response to industrial buyer complaints: Suggestions for improved vendor performance and customer loyalty. Journal of Business \& Industrial Marketing, 11 (1), 77-89.

Hansen, S. W., Powers, T. L., \& Swan, J. E. (1997a). Modeling industrial buyer complaints: Implications for satisfying and saving customers. Journal of Marketing Theory \& Practice, 5 (4), 12-21.

Hansen, S. W., Swan, J. E., \& Powers, T. L. (1997b). Vendor relationships as predictors of organizational buyer complaint response styles. Journal of Business Research, 40 (1), 65-77.

Harland, C. M. \& Knight, L. A. (2001). Supply network strategy. International Journal of Operations \& Production Management, 21 (4), 476-490.

Heide, J. B. \& George, J. (1988). The role of dependence balancing in safeguarding transaction-specific assets in conventional channels. Journal of Marketing, 52 (1), 20 35. 
Helfert, G., Ritter, T., \& Walter, A. (2002). Redefining market orientation from a relationship perspective: Theoretical considerations and empirical results. European Journal of Marketing, 36 (9/10), 1119-39.

Henneberg, S. C., Gruber, T., Ashnai, B., Naudé, P. \& Reppel, A. (2008). Understanding complaint management in close business-to-business relationships. 4th IMP Journal Seminar, Lancaster University Management School.

Herrmann, A., Huber, F. \& Gustaffson, A. (1997). From value-oriented quality improvement to customer satisfaction. In M. D. Johnson, A. Herrmann, F. Huber \& A. Gustafsson (Eds), Customer retention in the automotive industry (pp. 93-115). Wiesbaden: Gabler.

Hicks, D., Hansen, S. W., Swan, J. E. \& Powers (1996). Encouraging "friendly" complaint behaviour in industrial markets: Preventing a loss of customers and reputation. Industrial Marketing Management, 25 (4), 271-81.

Hingley, M. K. (2005). Power to all our friends? Living with imbalance in supplierretailer relationships. Industrial Marketing Management, 34 (8), 84-858.

Holmlund, M. (2004). Analyzing business relationships and distinguishing different interaction levels. Industrial Marketing Management, 33, 279-287.

Holmlund-Rytkönen, M. \& Strandvik, T. (2005). Stress in business relationships. Journal of Business and Industrial Marketing, 20 (1), 12-22.

Homburg, C. \& Fürst, A. (2005). How organizational complaint handling drives customer loyalty: An analysis of the mechanistic and the organic approach. Journal of Marketing, 69 (3), 95-114. 
Huemer, L. (2004). Balancing between stability and variety: identity and trust trade-offs in networks. Industrial Marketing Management, 33 (3), 251-260.

Jarratt, D. G. (1998). A strategic classification of business alliances: a qualitative perspective built from a study of small and medium-sized enterprises. Qualitative Market Research: An International Journal, 1(1), 39-49.

Jarrat, D. \& Morrison, M. (2003). Dependence and the application of power and control in major business relationships: A study of manufacturing and service frims in the business-to-business sector. Journal of Strategic Marketing, 11, 235-253.

Johnston, R. \& Mehra, S. (2002). Best-practice complaint management. Academy of Management Executive, 16 (4), 145-54.

Johnston, W. J., Leach, M. P., \& Liu, A. H. (1999). Theory testing using case studies in business-to-business research. Industrial Marketing Management, 28 (3), 201-13.

Johnston, W. J. \& Lewin, J. E. (1996). Organizational buying behavior: Toward an integrative framework. Journal of Business Research, 35 (1), 1-15.

Jüttner, U., Christopher, M., \& Baker, S. (2007). Demand chain management integrating marketing and supply chain management. Industrial Marketing Management, 36 (3), $377-392$

Krippendorff, K. (2004). Content Analysis. Thousand Oaks: Sage.

Lambe, C. J., Spekman, R. E., \& Hunt, S. D. (2000). Interimistic relational exchange: Conceptualization and propositional development. Journal of the Academy of Marketing Science, 28 (2), 212-26. 
Liljander, V. \& Strandvik, T. (1993). Difference comparison standards as determinants of service quality. Journal of Consumer Satisfaction, Dissatisfaction and Complaining Behaivour, 6, 118-132.

Low, H. \& Koon, B. (1997). Managing business relationships and positions in industrial networks. Industrial Marketing Management, 26 (2), 189-202.

Luo, Y. (2002), Building trust in cross-cultural collaborations: Toward a contingency perspective. Journal of Management, 28 (5), 669-694.

Maxham III, J. G. \& Netemeyer, R. G. (2003). Firms reap what they sow: The effects of shared values and perceived organizational justice on customers' evaluations of complaint handling. Journal of Marketing, 67 (1), 46-62.

McNally, R. C. \& Griffin, A. (2007). A measure and initial test of managers' perceptions of relationship marketing in inter-organizational exchanges. Journal of the Academy of Marketing Science, 35 (3), 382-97.

Medlin, C. J. (2004). Interaction in business relationships: A time perspective. Industrial Marketing Management. 33, 185-193.

Möller, K. K. \& Halinen, A. (1999). Business relationships and networks. Industrial Marketing Management, 28 (5), 413-27.

Moore, D. L. \& Tarnai, J. (2002). Evaluating nonresponse error in mail surveys. In R. M. Groves, D. A. Dillman, J. L. Eltinge, \& R. J. A. Little (Eds.), Survey nonresponse (pp. 197-211). New York: Wiley.

Morgan, R. M. \& Hunt, S. D. (1994). The commitment-trust theory of relationship marketing. Journal of Marketing, 58 (3), 20-38. 
Mouzas, S., Henneberg, S. C., \& Naudé, P. (2007). Trust and reliance in business relationships. European Journal of Marketing, 41 (9/10), 1016-1032.

Mouzas S., Henneberg S. C., \& Naudé, P. (2008). Developing network insight. Industrial Marketing Management, 37 (2), 167-80.

Ngobo, P. V. (1997). The standards issue: an accessibility-diagnosticity perspective. Journal of Consumer Satisfaction, Dissatisfaction and Complaining Behavior, 10, $61-79$.

Ojasalo, J. (2004). Key network management. Industrial Marketing Management, 33 (3), 195-206.

Olson, J. C. \& Reynolds, T. J. (1983). Understanding consumers' cognitive structures: Implications for marketing strategy. In L. Percy \& A. G. Woodside (Eds.), Advertising and consumer psychology (pp. 77-90). Lexington, MA: Lexington Books.

Ordanini, A., Micelli, S., \& Di Maria, E. (2004). Failure and success of b-to-b exchange business models: A contingent analysis of their Performance. European Management Journal, 22 (3), p281-289

Parasuraman, A., Zeithaml, V. A. \& Berry, L. L. (1988). SERVQUAL: A multiple-item scale for measuring consumer perceptions of service quality. Journal of Retailing, 64 (1), 12-40.

Parolini, C. (1999). The value net. Chichester: Wiley.

Perrien, J., Paradis, S., \& Banting, P. M. (1995). Dissolution of a relationship: The salesforce perception. Industrial Marketing Management, 24 (4), 317-27. 
Pieters, R., Botschen, G., \& Thelen, E. M. (1998), Customer desire expectations about service employees: An analysis of hierarchical relations, Psychology \& Marketing , $15(8), 755-773$.

Rauyruen P. \& Miller, K. E. (2007). Relationship quality as a predictor of b2b customer loyalty. Journal of Business Research, 60 (1), 21-31.

Reppel, A., Szmigin, I., \& Gruber, T. (2006). The ipod phenomenon: Identifying a market leader's secrets through qualitative marketing research. Journal of Product \& Brand Management, 15 (4), 239-49.

Reynolds, T. J. \& Gutman, J. (1988). Laddering theory, method, analysis, and interpretation. Journal of Advertising Research, 28 (1), 11-31.

Reynolds, T. J., Dethloff, C., \& Westberg, S. J. (2001). Advances in Laddering. In T. J. Reynolds \& J. C. Olson (Eds.), Understanding Consumer Decision Making - The Means-End Approach to Marketing and Advertising Strategy (pp. 91-118). Mahwah, NJ: Lawrence Erlbaum Associates.

Ringberg, T. \& Gupta, S. F. (2003). The importance of understanding the symbolic world of customers in asymmetric business-to-business relationships. Journal of Business \& Industrial Marketing, 18 (6/7), 607-26.

Ringberg, T., Odekerken-Schröder, G. \& Christensen, G. L. (2007). A cultural models approach to service recovery. Journal of Marketing, 71, 194-214.

Ritter, T. (1999). The networking company. Industrial Marketing Management, 28 (5), 467-79.

Ritter, T. \& Gemunden, H. G. (2003). Network competence: Its impact on innovation success and its antecedents. Journal of Business Research, 56 (9), 745-55. 
Rokeach, M. J. (1973). The nature of human values. New York, NY: Free Press.

Saad, M., Jones, M. \& James, P. (2002). A review of the progress towards the adoption of supply chain management (SCM) relationships in construction. European Journal of Purchasing \& Supply Management, 8, 173-183.

Sanderson, J. (2004). Opportunity and constraint in business-to-business relationships: Insights from strategic choice and zone of manoeuvre. Supply Chain Management, 9 (5), 392-401.

Schoorman, F. D., Mayer, R. C., \& Davis, J. H. (2007). An integrative model of organizational trust: Past, present, and future. Academy of Management Review, 32 (2), 344-54.

Schurr, P. H. (2007). Buyer-seller relationship development episodes: Theories and methods. Journal of Business and Industrial Marketing, 22 (3), 161-170.

Schurr, P. H., Hedaa, L. \& Gersbro, J. (2008). Interaction episodes as engines of relationship change. Journal of Business Research, 61, 877-884.

Schwartz, S. H. (1992). Universals in the content and structure of values: Theoretical advances and empirical tests in 20 countries. In Mark P. Zanna (Ed.), Advances in experimental social psychology (pp. 1-65). San Diego, CA: Academic Press.

Singh, J. (1990). A typology of consumer dissatisfaction response styles. Journal of Retailing, 66 (1), 57-99.

Swan, J. E. \& Coombs, L. J. (1976). Product performance and customer satisfaction: a new concept. Journal of Marketing, 40 (2), 25-33.

Stabell, C. B. \& Fjeldstad, Ø. D. (1998). Configuring value for competitive advantage: On chains, shop, and networks. Strategic Management Journal, 19), 413-37. 
Strauss, A. \& Corbin, J. M. (1998). Basics of qualitative research: Techniques and procedures for developing grounded theory. Thousand Oaks, CA: Sage.

Sutton-Brady, C. (2008). As time goes by: Examining the paradox of stability and change in business networks. Journal of Business Research, 61, 968-973.

Svensson, G. (2004). Vulnerability in business relationships: the gap between dependence and trust. Journal of Business \& Industrial Marketing, 19 (7), 469-483.

Tax, S. S., Brown, S. W., \& Chandrashekaran, M. (1998). Customer evaluations of service complaint experiences: Implications for relationship marketing. Journal of Marketing, 62 (2), 60-76.

Tellefsen, T. \& Thomas, G. P. (2005). The antecedents and consequences of organizational and personal commitment in business service relationships, Industrial Marketing Management, 34 (1), 23-37.

Trawick, I. F. \& Swan, J. E. (1981). A model of industrial satisfaction/complaining behaviour. Industrial Marketing Management, 10 (1), 23-30.

Tronvoll, B. (2007). Customer complaint behaviour from the perspective of the servicedominant logic of marketing. Managing Service Quality, 17 (6), 601-20.

Tyler, K. \& Stanley, E. (2007). The role of trust in financial services business relationships, Journal of Services Marketing, 21 (5), 334-344.

Ulaga, W. \& Eggert, A. (2006). Value-based differentiation in business relationships: Gaining and sustaining key supplier status. Journal of Marketing, 70 (1), 119-36.

Uzzi, B. (1997). Social structure and competition in interfirm networks: The paradox of embeddedness. Administrative Science Quarterly, 42 (1), 35-67. 
Vaaland, T. I. (2006), When conflict communication threatens the business relationship: Lessons from the "Balder" story. Journal of Business-to-Business Marketing, 13 (2), $3-25$

Vaaland, T. I. \& Håkansson (2003). Exploring interorganizational conflict in complex projects. Industrial Marketing Management, 32, 127-138.

Van Rekom, J. \& Wierenga, B. (2007). On the hierarchical nature of means-end relationships in laddering data. Journal of Business Research, 60 (4), 401-10.

Voss, R., Gruber, T., \& Szmigin, I. (2007). Service quality in higher education: The role of student expectations. Journal of Business Research, 60 (9), 949-59.

Walker, B. A. \& Olson, J. C. (1991). Means-end chains - connecting products with self. Journal of Business Research, 22 (2), 111-18.

Walter, A. (1999). Relationship promoters. Industrial Marketing Management, 28, 537551

Wood, R. T. A., Griffiths, M. D., \& Eatough, V. (2004). Online data collection from video game players: methodological issues. CyberPsychology \& Behaviour, 7 (5), 511- 518

Williams, A. \& Rao, C. P. (1980). Industrial buyer complaining behaviour. Industrial Marketing Management, 9 (4), 299-304.

Young, L. (2006). Trust: looking forward and back. Journal of Business \& Industrial Marketing, 21 (7), 439-445. 
Table 1: Implication matrix

\begin{tabular}{|c|c|c|c|c|c|c|c|c|c|c|}
\hline & 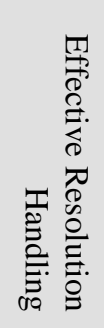 & 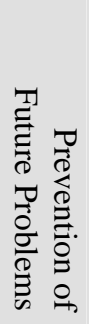 & 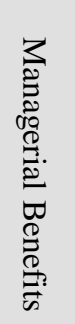 & 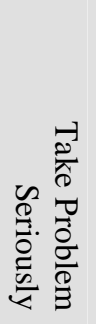 & 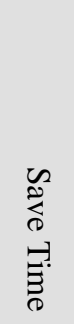 & 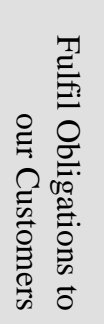 & $\begin{array}{l}\delta \\
\stackrel{0}{0} \\
\stackrel{0}{0} \\
\stackrel{0}{0}\end{array}$ & 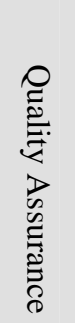 & 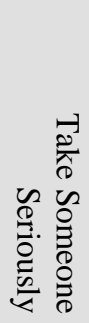 & 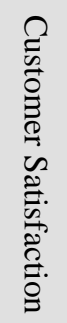 \\
\hline Take Quick Action & $5 / 5$ & $1 / 4$ & $3 / 6$ & $4 / 4$ & $2 / 7$ & $2 / 6$ & $/ 1$ & 12 & $1 / 4$ & $/ 3$ \\
\hline $\begin{array}{l}\text { Understand } \\
\text { Problem }\end{array}$ & $3 / 3$ & $4 / 8$ & & & $1 / 1$ & 12 & & $1 / 2$ & $2 / 2$ & \\
\hline Honesty & $1 / 1$ & $/ 1$ & $1 / 3$ & $1 / 1$ & & & 12 & & & \\
\hline Motivation & $1 / 1$ & $1 / 1$ & $1 / 1$ & $/ 1$ & $/ 1$ & $/ 1$ & $/ 1$ & & & $1 / 1$ \\
\hline Responsibility & $1 / 2$ & $/ 1$ & $1 / 1$ & $1 / 1$ & $1 / 2$ & & & $/ 1$ & $1 / 1$ & $/ 1$ \\
\hline Openness & $1 / 2$ & $1 / 2$ & $/ 2$ & & & & $1 / 1$ & & & \\
\hline Manners & $1 / 3$ & & & $3 / 3$ & & & & & $/ 1$ & \\
\hline Empathy & $1 / 4$ & $/ 1$ & & $2 / 2$ & & $/ 1$ & & & $/ 1$ & $/ 1$ \\
\hline Active Listening & $1 / 2$ & & & $1 / 1$ & & $/ 1$ & & $/ 1$ & $1 / 1$ & $/ 1$ \\
\hline Commit Resources & & & $/ 1$ & $/ 1$ & $1 / 1$ & & $1 / 1$ & & $1 / 1$ & $/ 2$ \\
\hline Cooperate & $1 / 1$ & $/ 2$ & $1 / 2$ & & & $/ 1$ & & & & \\
\hline Solution & & $7 / 7$ & $4 / 5$ & $1 / 1$ & $6 / 7$ & $2 / 4$ & $1 / 1$ & $1 / 3$ & $1 / 1$ & $2 / 2$ \\
\hline Financial Benefits & & & & & & & & & & $1 / 1$ \\
\hline $\begin{array}{l}\text { Effective } \\
\text { Resolution } \\
\text { Handling }\end{array}$ & & $2 / 4$ & $/ 1$ & $1 / 1$ & $/ 1$ & $/ 1$ & $1 / 2$ & 12 & $/ 1$ & $2 / 2$ \\
\hline $\begin{array}{l}\text { Prevention of } \\
\text { Future Problems }\end{array}$ & & & $1 / 1$ & & & $3 / 3$ & $1 / 1$ & $4 / 4$ & & $1 / 1$ \\
\hline $\begin{array}{l}\text { Managerial } \\
\text { Benefits }\end{array}$ & & & & & & $4 / / 4$ & & & & $1 / 2$ \\
\hline $\begin{array}{l}\text { Take Problem } \\
\text { Seriously }\end{array}$ & $3 / 3$ & $1 / 2$ & $1 / 1$ & & & & $3 / 3$ & $1 / 1$ & $1 / 1$ & \\
\hline Save Time & & & $2 / 2$ & & & & & & & \\
\hline
\end{tabular}

Note: The number of direct implications appears on the left of the dash; total implications (direct and indirect relations) are to the right of the dash. For example, "Take Quick Action" leads to "Save Time" twice directly and five times indirectly (i.e. total implications minus direct implications). Thus, two respondents say that the supplier's ability to take quick action directly helps buying companies to save time, whereas five respondents sequentially relate the two elements with another element in between. 
Figure 1: Example for laddering process

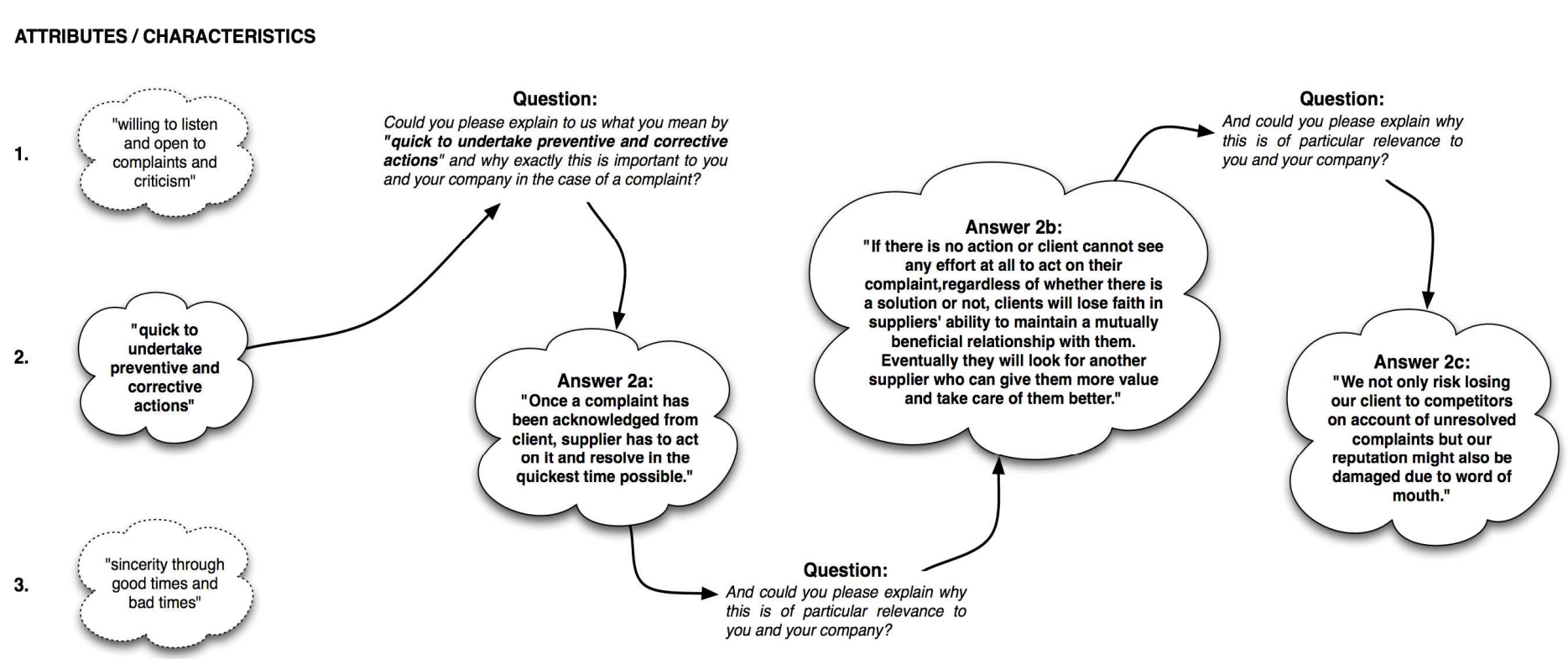


Figure 2: Hierarchical value map for large companies

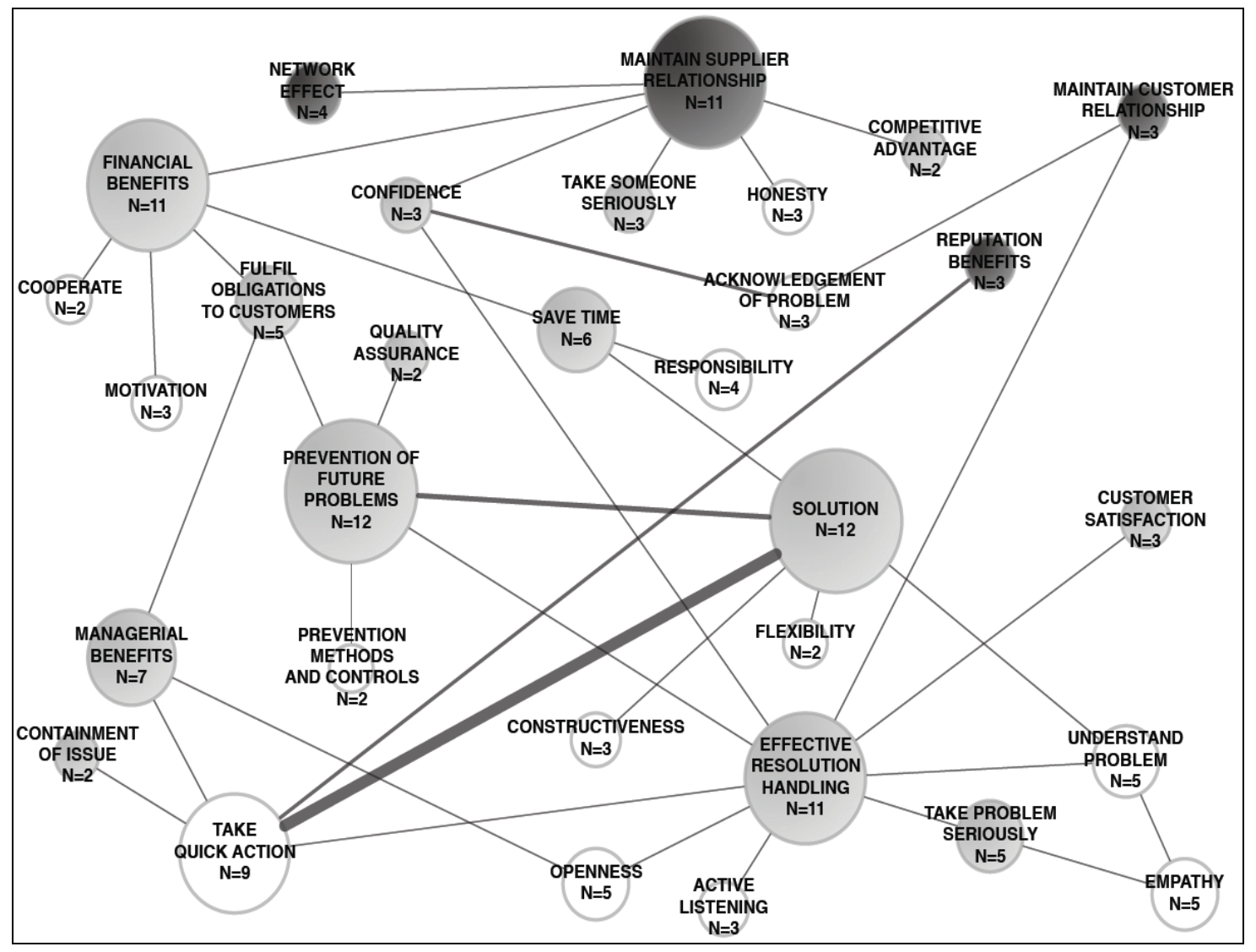

Note: Attributes=white, consequences=grey and values=black; numbers $(\mathrm{N})$ refer to frequency with which constructs were mentioned; the thickness of the lines linking constructs indicates the tie strength between them. Due to the chosen association cut-off, the Ns in this figure do not correspond with the Ns per construct in the tables in the appendix (A2-A4). 
Figure 3: Hierarchical value map for small companies

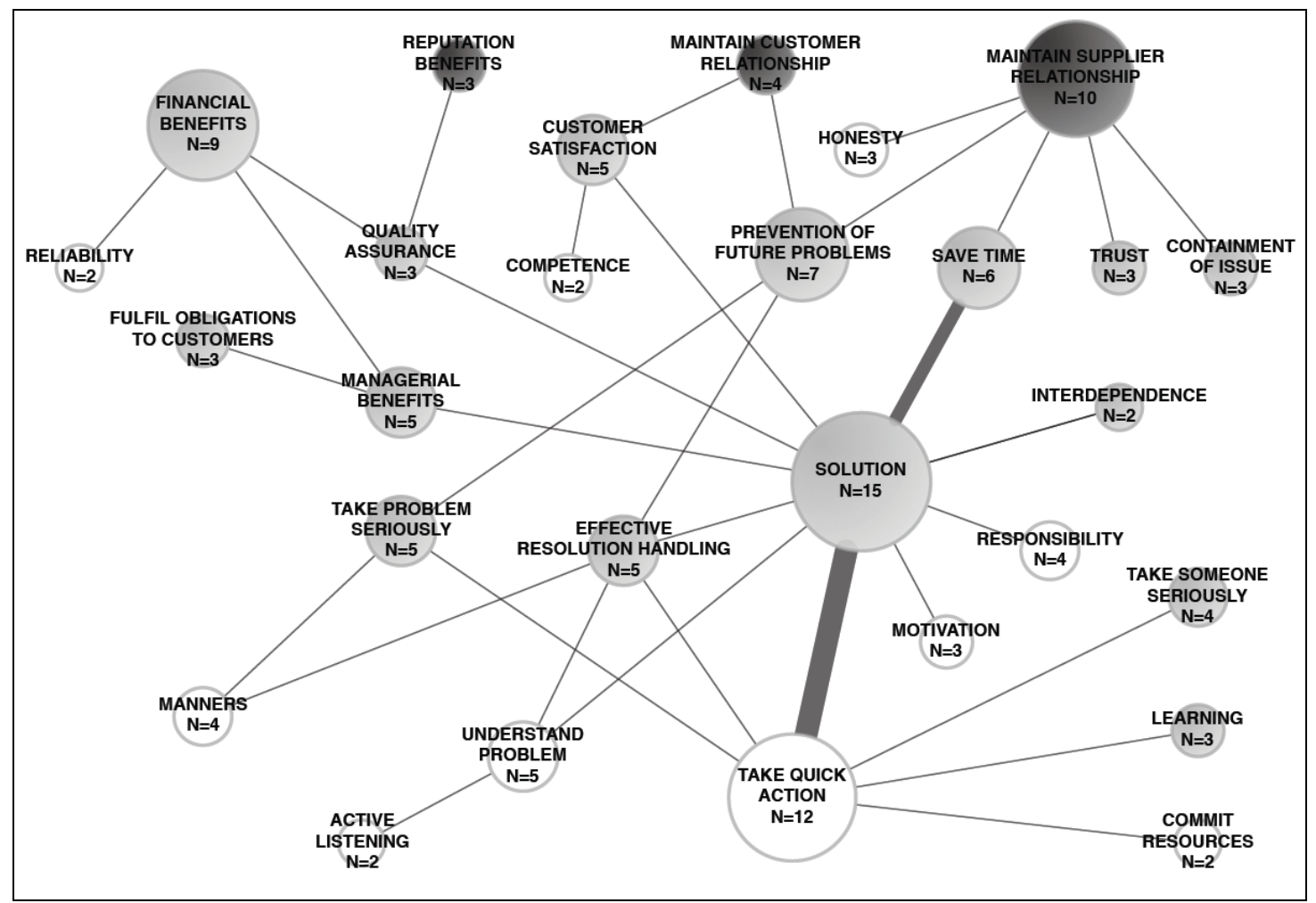

Note: Attributes=white, consequences=grey and values=black; numbers $(\mathrm{N})$ refer to frequency with which constructs were mentioned; the thickness of the lines linking constructs indicates the tie strength between them. Due to the chosen association cut-off, the Ns in this figure do not correspond with the Ns per construct in the tables in the appendix (A2-A4). 


\section{Appendix}

Table A1: Overview of business complaint behaviour/management literature

\begin{tabular}{|c|c|c|c|}
\hline Source & $\begin{array}{c}\text { Business complaint } \\
\text { emphasis }\end{array}$ & Method & Findings \\
\hline $\begin{array}{l}\text { Williams and Rao } \\
\text { (1980) }\end{array}$ & - buyer complaining behaviour & - conceptual & $\begin{array}{l}\text { - developed a model consisting of } \\
\text { antecedents influencing complaint } \\
\text { behaviour }\end{array}$ \\
\hline $\begin{array}{l}\text { Trawick and Swan } \\
\text { (1981) }\end{array}$ & $\begin{array}{l}\text { - industrial satisfaction/complaining } \\
\text { behaviour }\end{array}$ & $\begin{array}{l}\text { - Quantitative, mail survey }(\mathrm{n}= \\
90)\end{array}$ & $\begin{array}{l}\text { - developed a model of the purchaser's } \\
\text { satisfaction with supplier response to a } \\
\text { formal buyer complaint }\end{array}$ \\
\hline $\begin{array}{l}\text { Dart and Freeman } \\
\text { (1994) }\end{array}$ & $\begin{array}{l}\text { - examined the response style of } \\
\text { unsatisfied business clients }\end{array}$ & $\begin{array}{l}\text { - Quantitative, mail survey } \\
\text { - Factor, cluster and } \\
\text { discrimination analysis }\end{array}$ & - 4 types of complaint behaviour \\
\hline Perrien et al. (1995) & $\begin{array}{l}\text { - attempted to understand the } \\
\text { dissolution of business } \\
\text { relationship }\end{array}$ & $\begin{array}{l}\text { - } \text { Qualitative }(\mathrm{n}=50) \\
\text { - }\end{array}$ & $\begin{array}{l}\text { account manager/front line people } \\
\text { account for } 30 \% \text { of the dissolution } \\
\text { reason (responsible for poor complaint } \\
\text { resolution and satisfaction among } \\
\text { other issues), secondary data }\end{array}$ \\
\hline Hansen et al. (1996a) & $\begin{array}{l}\text { - dissatisfaction response styles } \\
\text { - conceptualized friendly } \\
\text { complaints (instead of exit or } \\
\text { involving third parties) }\end{array}$ & $\begin{array}{l}\text { - } \text { Quantitative, survey }(\mathrm{n}=162) \\
\text { - } \\
\text { interviews }(\mathrm{n}=20) \\
\text { - } \\
\text { Cluster analysis }\end{array}$ & $\begin{array}{l}\text { - four dissatisfaction response styles } \\
\text { - } \\
\text { suggests actions to reduce customer } \\
\text { dissatisfaction complaints }\end{array}$ \\
\hline Hansen et al. (1996b) & $\begin{array}{l}\text { - attempted to understand the } \\
\text { industrial complaining process } \\
\text { and positive vs. negative } \\
\text { complaints }\end{array}$ & $\begin{array}{l}\text { - } \text { Quantitative, survey }(\mathrm{n}=162) \\
\text { - } \text { Qualitative, in-depth } \\
\text { interviews }(\mathrm{n}=20) \\
\text { - } \\
\text { chi-squares and t-tests }\end{array}$ & $\begin{array}{l}\text { analyzed the perceived effectiveness } \\
\text { of marketer responses to complaints }\end{array}$ \\
\hline Hansen et al. (1997a) & - industrial complaints & $\begin{array}{l}\text { - conceptual meta-study of } \\
\text { customer complaint behaviour } \\
\text { literature }\end{array}$ & $\begin{array}{l}\text { - developed a model of industrial } \\
\text { complaints }\end{array}$ \\
\hline Hansen et al. (1997b) & - same as above & - $\quad$ same as above & $\begin{array}{l}\text { identified a set of variables useful for } \\
\text { predicting styles of buyer complaint } \\
\text { behaviour }\end{array}$ \\
\hline Hansen (1997) & $\begin{array}{l}\text { - } \quad \text { showed power as a predictor of } \\
\text { industrial complaining styles }\end{array}$ & - Quantitative, survey $(\mathrm{n}=162)$ & $\begin{array}{l}\text { - referent and punishment power play a } \\
\text { major role in predicting of } \\
\text { complaining styles }\end{array}$ \\
\hline $\begin{array}{l}\text { Homburg and Fürst } \\
(\mathbf{2 0 0 5 )}\end{array}$ & $\begin{array}{l}\text { - addressed how organizational } \\
\text { complaint handling drives } \\
\text { customer loyalty }\end{array}$ & $\begin{array}{l}\text { Quantitative, survey }(\mathrm{n}=110 \\
\text { dyads }) \\
\text { - combined B2B/B2C survey }\end{array}$ & $\begin{array}{l}\text { mechanistic approach has a stronger } \\
\text { total impact than organic approach } \\
\text { - effects of the mechanic approach are } \\
\text { stronger in B2C than in B2B and in } \\
\text { service than in manufacturing firms }\end{array}$ \\
\hline
\end{tabular}


Note for tables A2-A4: The constructs appear in alphabetical order; $\mathrm{n}$ refers to the frequency with which this construct was mentioned. Due to the chosen cut-off level, the Ns in these tables do not correspond with the Ns in the hierarchical value maps (figures 2 and 3).

Table A2: Overview list of all attributes

\begin{tabular}{|c|c|c|c|}
\hline Attribute & $\begin{array}{l}\text { Large } \\
\text { Companies }\end{array}$ & $\begin{array}{l}\text { Small } \\
\text { Companies }\end{array}$ & Example Verbatim \\
\hline Accuracy & $\mathrm{n}=0$ & $\mathrm{n}=1$ & $\begin{array}{l}\text { "supplier should produce accurate } \\
\text { figures" }\end{array}$ \\
\hline $\begin{array}{l}\text { Acknowledgement } \\
\text { of Problem }\end{array}$ & $\mathrm{n}=9$ & $\mathrm{n}=1$ & $\begin{array}{l}\text { "the problem has to acknowledged } \\
\text { immediately" }\end{array}$ \\
\hline $\begin{array}{l}\text { Active } \\
\text { Listening }\end{array}$ & $\mathrm{n}=3$ & $\mathrm{n}=2$ & $\begin{array}{l}\text { "they have to listen to the problem } \\
\text { in full" }\end{array}$ \\
\hline Authority & $\mathrm{n}=1$ & $\mathrm{n}=0$ & $\begin{array}{l}\text { "contact person needs authority to } \\
\text { sort out problem himself" }\end{array}$ \\
\hline $\begin{array}{l}\text { Commit } \\
\text { Resources }\end{array}$ & $\mathrm{n}=3$ & $n=3$ & $\begin{array}{l}\text { "need to commit time and people } \\
\text { to problem" }\end{array}$ \\
\hline Communicate & $\mathrm{n}=1$ & $\mathrm{n}=2$ & $\begin{array}{l}\text { "they have to always } \\
\text { communicate with us" }\end{array}$ \\
\hline Competence & $\mathrm{n}=0$ & $n=3$ & "do possess relevant skills" \\
\hline Constructiveness & $\mathrm{n}=3$ & $\mathrm{n}=0$ & $\begin{array}{l}\text { "want them to offer response that } \\
\text { is constructive" }\end{array}$ \\
\hline Cooperate & $\mathrm{n}=5$ & $\mathrm{n}=1$ & $\begin{array}{l}\text { "have to work closely together as } \\
\text { a team" }\end{array}$ \\
\hline Empathy & $\mathrm{n}=7$ & $\mathrm{n}=1$ & $\begin{array}{l}\text { "can understand what problems } \\
\text { mean to us " }\end{array}$ \\
\hline Feedback & $\mathrm{n}=5$ & $n=3$ & "update us on findings" \\
\hline Flexibility & $\mathrm{n}=3$ & $\mathrm{n}=0$ & "they should be flexible" \\
\hline $\begin{array}{l}\text { Good with } \\
\text { Administration }\end{array}$ & $\mathrm{n}=0$ & $\mathrm{n}=1$ & $\begin{array}{l}\text { "should be good with } \\
\text { administration" }\end{array}$ \\
\hline Helpfulness & $\mathrm{n}=0$ & $\mathrm{n}=2$ & "indicates helpfulness" \\
\hline Honesty & $\mathrm{n}=7$ & $\mathrm{n}=5$ & "I want to be told the truth" \\
\hline Intelligence & $\mathrm{n}=1$ & $\mathrm{n}=0$ & "should be intelligent" \\
\hline Manners & $\mathrm{n}=1$ & $\mathrm{n}=6$ & "should give courteous response" \\
\hline Motivation & $\mathrm{n}=7$ & $\mathrm{n}=4$ & $\begin{array}{l}\text { "be willing to do the best he can } \\
\text { do" }\end{array}$ \\
\hline Openness & $\mathrm{n}=10$ & $\mathrm{n}=0$ & "should be open to listen" \\
\hline $\begin{array}{l}\text { Prevention } \\
\text { Methods and } \\
\text { Controls } \\
\end{array}$ & $\mathrm{n}=2$ & $\mathrm{n}=0$ & $\begin{array}{l}\text { "should have prevention controls } \\
\text { in place" }\end{array}$ \\
\hline Proactiveness & $\mathrm{n}=1$ & $\mathrm{n}=5$ & $\begin{array}{l}\text { "offer me information before I ask } \\
\text { for it" }\end{array}$ \\
\hline
\end{tabular}




\begin{tabular}{|l|l|l|l|}
\hline Reliability & $\mathrm{n}=2$ & $\mathrm{n}=3$ & "deliver on promises" \\
\hline Responsibility & $\mathrm{n}=4$ & $\mathrm{n}=7$ & $\begin{array}{l}\text { "want one person to take } \\
\text { responsibility" }\end{array}$ \\
\hline Supportiveness & $\mathrm{n}=1$ & $\mathrm{n}=0$ & $\begin{array}{l}\text { "this indicates supportiveness by } \\
\text { the supplier" }\end{array}$ \\
\hline Take Quick Action & $\mathrm{n}=20$ & $\mathrm{n}=21$ & $\begin{array}{l}\text { "want them to deal with problem } \\
\text { quickly" }\end{array}$ \\
\hline Transparency & $\mathrm{n}=1$ & $\mathrm{n}=3$ & $\begin{array}{l}\text { "share information and facts and } \\
\text { give insights" }\end{array}$ \\
\hline Trustworthiness & $\mathrm{n}=3$ & $\mathrm{n}=0$ & "should be trustworthy" \\
\hline $\begin{array}{l}\text { Understand } \\
\text { Problem }\end{array}$ & $\mathrm{n}=12$ & $\mathrm{n}=8$ & $\begin{array}{l}\text { "should understand why problem } \\
\text { occurred" }\end{array}$ \\
\hline
\end{tabular}

Table A3: Overview list of all consequences

\begin{tabular}{|l|l|l|l|}
\hline Consequence & $\begin{array}{l}\text { Large } \\
\text { Companies }\end{array}$ & $\begin{array}{l}\text { Small } \\
\text { Companies }\end{array}$ & Example Verbatim \\
\hline Avoid Complaints & $\mathrm{n}=0$ & $\mathrm{n}=2$ & "may avoid need for complaint" \\
\hline Certainty & $\mathrm{n}=0$ & $\mathrm{n}=1$ & "otherwise uncertainty" \\
\hline Commitment & $\mathrm{n}=1$ & $\mathrm{n}=1$ & "then they show commitment" \\
\hline $\begin{array}{l}\text { Concentrate on } \\
\text { Other Issues }\end{array}$ & $\mathrm{n}=4$ & $\mathrm{n}=0$ & $\begin{array}{l}\text { "our company can focus on other } \\
\text { issues" }\end{array}$ \\
\hline $\begin{array}{l}\text { Competitive } \\
\text { Advantage }\end{array}$ & $\mathrm{n}=6$ & $\mathrm{n}=0$ & $\begin{array}{l}\text { "generates competitive } \\
\text { advantage" }\end{array}$ \\
\hline Confidence & $\mathrm{n}=11$ & $\mathrm{n}=4$ & $\begin{array}{l}\text { "to restore my confidence" } \\
\text { "keep small issues from turning } \\
\text { into big ones" }\end{array}$ \\
\hline $\begin{array}{l}\text { Issue } \\
\text { Credibility }\end{array}$ & $\mathrm{n}=2$ & $\mathrm{n}=5$ & $\begin{array}{l}\text { "otherwise supplier loses } \\
\text { credibility" }\end{array}$ \\
\hline $\begin{array}{l}\text { Customer } \\
\text { Satisfaction }\end{array}$ & $\mathrm{n}=4$ & $\mathrm{n}=6$ & $\begin{array}{l}\text { "ensures continuity of supplies to } \\
\text { satisfy customers" }\end{array}$ \\
\hline $\begin{array}{l}\text { Differentiation } \\
\text { "because good relationships help } \\
\text { us to differentiate ourselves" }\end{array}$ \\
\hline $\begin{array}{l}\text { Effective } \\
\text { Resolution } \\
\text { Handling }\end{array}$ & $\mathrm{n}=2$ & $\mathrm{n}=0$ & $\begin{array}{l}\text { "indicates that complaint is dealt } \\
\text { with" }\end{array}$ \\
\hline Financial Benefits & $\mathrm{n}=26$ & $\mathrm{n}=12$ & $\mathrm{n}=4$ \\
\hline $\begin{array}{l}\text { Fulfil Obligations } \\
\text { to our Customers }\end{array}$ & $\mathrm{n}=11$ & $\mathrm{n}=0$ & $\begin{array}{l}\text { "this is fundamental to delivering } \\
\text { to our customers" }\end{array}$ \\
\hline $\begin{array}{l}\text { Good Working } \\
\text { Environment }\end{array}$ & $\mathrm{n}=8$ & $\begin{array}{l}\text { "fosters good working } \\
\text { environment" }\end{array}$ \\
\hline
\end{tabular}




\begin{tabular}{|c|c|c|c|}
\hline Interdependence & $\mathrm{n}=2$ & $\mathrm{n}=3$ & "do not have other suppliers" \\
\hline Learning & $\mathrm{n}=0$ & $\mathrm{n}=3$ & "learn for the future" \\
\hline $\begin{array}{l}\text { Legal } \\
\text { Responsibility }\end{array}$ & $\mathrm{n}=0$ & $\mathrm{n}=1$ & "it is their legal responsibility" \\
\hline Loyalty & $\mathrm{n}=0$ & $\mathrm{n}=1$ & "necessary for allegiance" \\
\hline $\begin{array}{l}\text { Managerial } \\
\text { Benefits }\end{array}$ & $\mathrm{n}=13$ & $\mathrm{n}=7$ & $\begin{array}{l}\text { "avoid internal production and } \\
\text { planning issues" }\end{array}$ \\
\hline $\begin{array}{l}\text { Prevention of } \\
\text { Future Problems }\end{array}$ & $\mathrm{n}=19$ & $\mathrm{n}=9$ & $\begin{array}{l}\text { "to stop problem from } \\
\text { reoccurring" }\end{array}$ \\
\hline Quality Assurance & $\mathrm{n}=4$ & $\mathrm{n}=9$ & "ensure quality of products" \\
\hline $\begin{array}{l}\text { Reduction of } \\
\text { System Rigidity }\end{array}$ & $\mathrm{n}=1$ & $\mathrm{n}=0$ & $\begin{array}{l}\text { "issues are caused by suppliers } \\
\text { fixed systems" }\end{array}$ \\
\hline Save Time & $\mathrm{n}=9$ & $\mathrm{n}=6$ & "it saves time, otherwise delays" \\
\hline Solution & $\mathrm{n}=28$ & $\mathrm{n}=27$ & "to solve the problem correctly" \\
\hline $\begin{array}{l}\text { Take Problem } \\
\text { Seriously }\end{array}$ & $\mathrm{n}=6$ & $\mathrm{n}=9$ & $\begin{array}{l}\text { "good supplier takes any } \\
\text { complaint seriously" }\end{array}$ \\
\hline $\begin{array}{l}\text { Take Someone } \\
\text { Seriously }\end{array}$ & $\mathrm{n}=4$ & $\mathrm{n}=6$ & "so I feel I matter to the supplier" \\
\hline Trust & $\mathrm{n}=1$ & $\mathrm{n}=6$ & $\begin{array}{l}\text { "have to trust that they do what } \\
\text { they say" }\end{array}$ \\
\hline
\end{tabular}

Table A4: Overview list of all values

\begin{tabular}{|l|l|l|l|}
\hline Value & $\begin{array}{l}\text { Large } \\
\text { Companies }\end{array}$ & $\begin{array}{l}\text { Small } \\
\text { Companies }\end{array}$ & Example Verbatim \\
\hline Fairness & $\mathrm{n}=0$ & $\mathrm{n}=1$ & "demonstrates fairness" \\
\hline $\begin{array}{l}\text { Maintain Customer } \\
\text { Relationship }\end{array}$ & $\mathrm{n}=7$ & $\mathrm{n}=4$ & "otherwise risk losing customer" \\
\hline $\begin{array}{l}\text { Maintain Supplier } \\
\text { Relationship }\end{array}$ & $\mathrm{n}=33$ & $\mathrm{n}=22$ & $\begin{array}{l}\text { "avoids having to procure another } \\
\text { supplier" }\end{array}$ \\
\hline Network Effects & $\mathrm{n}=11$ & $\mathrm{n}=5$ & $\begin{array}{l}\text { "pass pressure from our customers } \\
\text { on to our suppliers" }\end{array}$ \\
\hline $\begin{array}{l}\text { Reputation } \\
\text { Benefits }\end{array}$ & $\mathrm{n}=4$ & $\mathrm{n}=6$ & $\begin{array}{l}\text { "otherwise our reputation is } \\
\text { impacted" }\end{array}$ \\
\hline Well Being & $\mathrm{n}=1$ & $\mathrm{n}=2$ & "everybody is happier" \\
\hline
\end{tabular}




\section{Table A5: Research questionnaire and example for laddering}

Note for table A5: the questionnaire was implemented online, i.e. the version shown here provides a template for the implementation of the questionnaire. Only Part III of the questionnaire pertains to the research project introduced. Thus, the other parts are not shown.

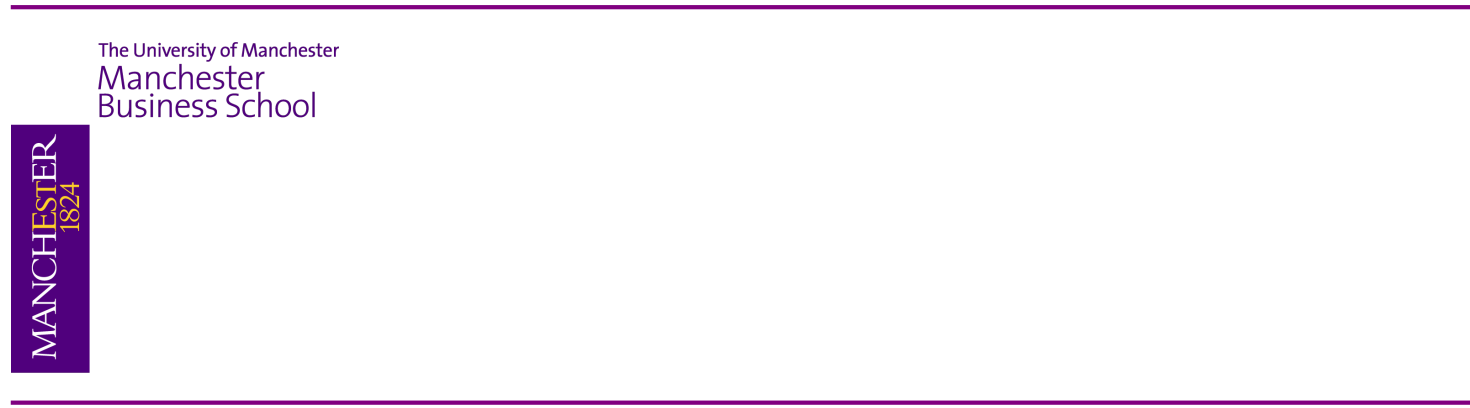

Dear Respondent

Many thanks for your participation in our research project on complaint management in business-to-business relationships. This questionnaire will take about $\mathbf{2 0}$ minutes to fill in. Your contribution is important to us. All of your responses will be treated anonymously and will not be shared with others.

Technical note: In order to ensure a successful submission of your answers, we suggest that you do not use the browser's 'back' or 'reload' buttons during this survey. These buttons are located in the upper navigation bar.

\section{Part III.}

In this part we are interested in finding out how you would like to be treated when something goes wrong in a business relationship and you complain to your supplier. . 
For this purpose, please think about the behaviours or characteristics of suppliers that are important to you. What should your suppliers do to handle your complaint, what kind of qualities or characteristics would you expect from them? Please do not describe past behaviours or characteristics of suppliers, but focus rather on how you would like them to act or behave.

III.1. Please think about the three most important attributes, behaviours or characteristics of good complaint handling by a supplier. Please be as specific as possible.
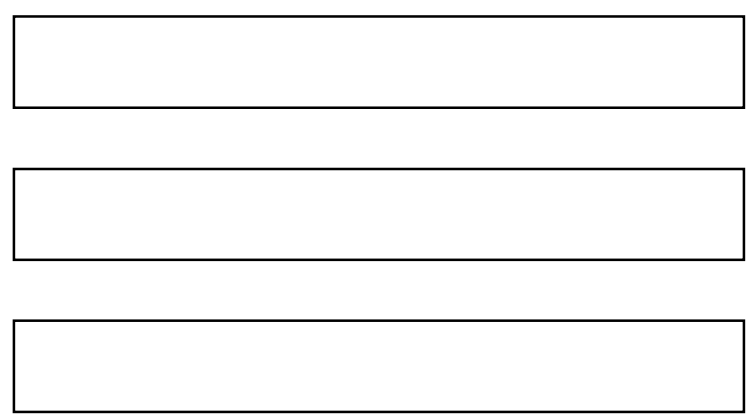

[Three free text boxes; answer text will be used in next questions]

Many thanks. We would now like to explore why you have chosen these aspects.

Therefore, we will ask you step by step about the reasons why they are important to you or your company in cases where you complain to your supplier.

III.2-4. You have (also) [use in permutations 3 and 4] stated that one of the most important attributes or characteristic of a supplier in cases of complaints should be “........."[insert one answer each from III.1.].

Could you please explain to us what you mean by this and why exactly this is important to you and your company in the case of a complaint? 


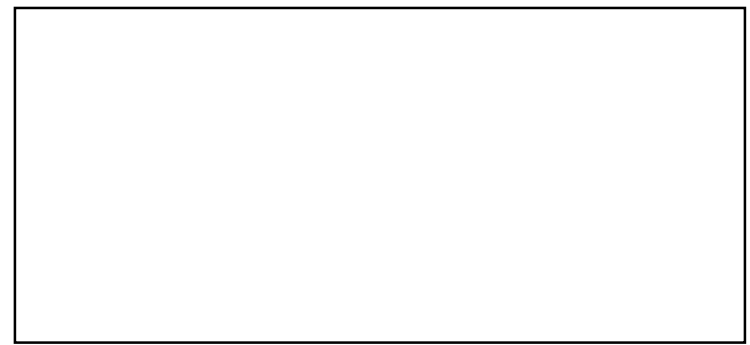

[open text box, with acknowledgement box bottom right, saying 'next'; followed by question:]

And why is what you indicated in the previous textbox important to you and your company?

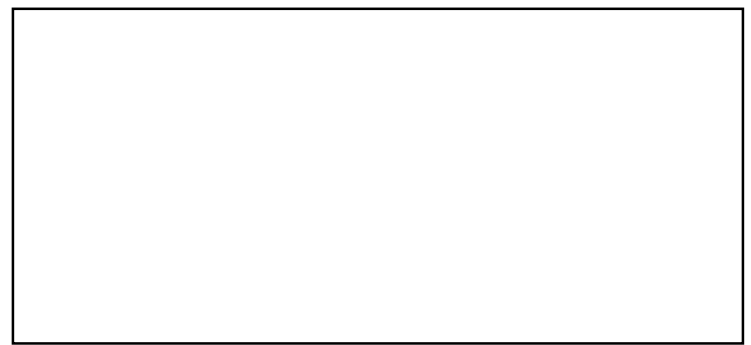

[open text box, with acknowledgement box bottom right, saying 'next'; followed by question:]

And why is what you indicated in the previous textbox of relevance to you and your company?

[option: I cannot think of any further reason for this. -> link to next question set;

option : Because of the following reasons: -> new open text box, with acknowledgement box bottom right, saying 'next'; going into loop]

\section{All your answers will be treated anonymously. We will not share your information with others and will only use the information as part of our research project.}

\section{Many thanks for your participation.}


SEND SURVEY ANSWERS

[Big button which saves answers]

MANY THANKS.

\section{Example for Part III - Characteristic 1}

You have stated that one of the most important attributes or characteristic of a supplier in cases of complaints should be "Competence".

Could you please explain to us what you mean by this and why exactly this is important to you and your company in the case of a complaint?

Should know what's going on

You wrote: "should know what is going on" And could you please explain why this is of particular relevance to you and your company?

To be able to solve problem

You wrote: "To be able to solve problem" And why is this specifically important to you and your company?

To make sure my customers get their products in time 
*Can you think of further reasons, why what you indicated in the textbox above is of significance to you and your company?

Choose only one of the following

[ No, I cannot think of any further reason for this.

C Yes, I can think of further reason(s) for this. 